\title{
Decentralisation of Policies Affecting Forests and Estate Crops in Kotawaringin Timur District, Central Kalimantan
}

\section{Anne Casson}
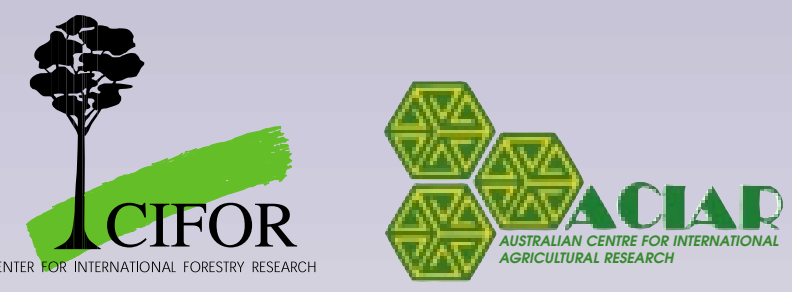


\section{CIFOR REPORTS ON DECENTRALISATION AND FORESTS IN INDONESIA}

\section{Synthesis of Major Findings}

Barr, C. and Resosudarmo, I.A.P. 2002. Decentralisation of forest administration in Indonesia: Implications for forest sustainability, community livelihoods, and economic development. Center for International Forestry Research, Bogor, Indonesia.

\section{District and Provincial Case Studies}

Case Study 1. McCarthy, J.F. 2001. Decentralisation, local communities and forest management in Barito Selatan District, Central Kalimantan. Center for International Forestry Research, Bogor, Indonesia.

Case Study 2. McCarthy, J.F. 2001. Decentralisation and forest management in Kapuas District, Central Kalimantan. Center for International Forestry Research, Bogor, Indonesia.

Case Study 3. Barr, C., Wollenberg, E., Limberg, G., Anau, N., Iwan, R., Sudana, I.M., Moeliono, M., and Djogo, T. 2001. The impacts of decentralisation on forests and forest-dependent communities in Malinau District, East Kalimantan. Center for International Forestry Research, Bogor, Indonesia.

Case Study 4. Casson, A. 2001. Decentralisation of policies affecting forests and estate crops in Kutai Barat District, East Kalimantan. Center for International Forestry Research, Bogor, Indonesia.

Case Study 5. Casson, A. 2001. Decentralisation of policies affecting forests and estate crops in Kotawaringin Timur District, Central Kalimantan. Center for International Forestry Research, Bogor, Indonesia.

Case Studies 6 and 7. Potter, L. and Badcock, S. 2001. The effects of Indonesia's decentralisation on forests and estate crops in Riau Province: Case studies of the original districts of Kampar and Indragiri Hulu. Center for International Forestry Research, Bogor, Indonesia.

Case Study 8. Soetarto, E., Sitorus, M.T.F. and Napiri, Y. 2001. Decentralisation of administration, policy making and forest management in West Kalimantan. Center for International Forestry Research, Bogor, Indonesia.

Case Study 9. Obidzinski, K. and Barr, C. 2002. The effects of decentralisation on forests and forest Industries in Berau District, East Kalimantan. Center for International Forestry Research, Bogor, Indonesia. 
Decentralisation of Policies Affecting Forests and Estate Crops in Kotawaringin Timur District, Central Kalimantan ${ }^{1}$

Anne Casson 
(c) 2001 by Center for International Forestry Research All rights reserved. Published in 2001

Printed by SMK Grafika Desa Putera, Indonesia

\section{ISBN 979-8764-83-8}

\section{Published by}

Center for International Forestry Research

Mailing address: P.O. Box 6596 JKPWB, Jakarta 10065, Indonesia

Office address: JI. CIFOR, Situ Gede, Sindang Barang, Bogor Barat 16680, Indonesia

Tel.: +62 (251) 622622; Fax: +62 (251) 622100

E-mail: cifor@cgiar.org

Web site: http://www.cifor.cgiar.org 


\title{
Decentralisation and Forests in Indonesia: An Overview of the Study
}

\author{
ince early-2000, the Center for International Forestry Research (CIFOR) has \\ $\checkmark$ conducted research on the decentralisation of forest administration and \\ policies affecting forests in Indonesia. This project has sought to document the \\ real and anticipated impacts of decentralisation on forest management, forest \\ community livelihoods, and economic development at the provincial and district \\ levels. During the initial phase of this research, CIFOR conducted case studies \\ in nine kabupaten or districts, in four provinces: Riau, East Kalimantan, Central \\ Kalimantan, and West Kalimantan. These case studies were carried out in 2000, \\ with follow up visits to some districts conducted in early 2001. As such, the \\ findings presented in the present report and the companion case studies reflect \\ the conditions and processes that existed in the study districts during the initial \\ phase of Indonesia's decentralisation process.
}

The following reports have been produced by this project. The first of these represents a synthesis of the major findings from the nine case studies, accompanied by a historical analysis of forest administration and forestry sector development in Indonesia, and a discussion of the origins and legal-regulatory basis of the nation's ongoing decentralisation process. Each of the nine case studies is published as a separate report (with the exception of the study districts in Riau, which have been combined) in order to make the information contained therein more readily accessible to decision-makers involved in the decentralisation process. It is hoped that readers of the case studies will refer to the synthesis report in order to situate the specific case study findings in a broader historical and policy context.

During 2002, CIFOR will publish additional case studies from research on decentralisation and forests in West Kalimantan, South Sulawesi and Irian Jaya. CIFOR also plans to carry out follow-up research at several of the original case study districts, and will publish periodic findings from the sites.

\section{Acknowledgements and Disclaimer}

CIFOR gratefully acknowledges the financial support of the Australian Center for International Agricultural Research (ACIAR) and the United Kingdom's Department for International Development (DFID). The opinions expressed in this report are the views of the author(s) and do not necessarily represent the official policy of CIFOR. These opinions, likewise, do not represent the official policy of ACIAR or DFID or any other organization involved in funding, conducting or disseminating this study.

A number of people provided a great deal of support and assistance for this research while I was in Central Kalimantan, Jakarta and Bogor. I would particularly like to 
thank the following people: numerous NGO personnel, The Nyaru Menteng Orang-utan Rehabilitation Centre, Neil Scotland (DFID), Rona Dennis (CIFOR), CINTROP and the local inhabitants of Kotawaringan Timur that gave their time while I was in the area. During the time of writing, the following people offered a great deal of support and encouragement: Chris Ballard (ANU), Colin Filer (ANU), Eric Wakker (AidEnvironment), Grahame Applegate (CIFOR), Hidayat Al-Hamid (ANU), Joyotee Smith (CIFOR), Ketut Deddy (WWF International), Liz Chidley (Down to Earth), Peter Kanowski (ANU), Stephen Midgley (CSIRO) and Yvonne Byron. My fellow colleagues have also helped to provide new insights, experience and expertise: Chris Barr (CIFOR), Ida Aju Pradnja Resosudarmo (CIFOR), Lesley Potter (University of Adelaide), John McCarthy (Murdoch University) and Simon Badcock (University of Adelaide). Finally I would like to thank Hendrik Segah (CINTROP), who accompanied me in the field when some of the fieldwork was undertaken in Kotawaringin Timur.

This paper was prepared for the Programme on the Underlying Causes of Deforestation, Center for International Forestry Research (CIFOR), Bogor, Indonesia.

Anne Casson is a Research Fellow of the Resource Management in AsiaPacific Project, the Australian National University, Australia. She undertook this work while based at CIFOR. This paper constituted partial fulfilment of her PhD. 


\section{Editor's Preface}

\section{Overview of Indonesia's Decentralisation Process}

Since late-1998, Indonesia has undergone a process of rapid and far-reaching decentralisation. With this process, considerable degrees of administrative and regulatory authority have been transferred from the national government in Jakarta to the country's provincial and district governments. This transfer of authority has occurred across broad segments of the nation's economy and has sharply redefined the roles and responsibilities of government agencies at each level of the nation's administrative structure. With the locus of decision-making shifting decisively away from the national government, Indonesia's ongoing decentralisation process marks a dramatic break from the highly-centralized system of governance that characterized Soeharto's New Order regime during the period 1966-1998.

To a significant extent, the process of decentralisation now occurring in Indonesia has been driven by the demands of provincial and district governments whose jurisdictions are rich in timber, petroleum, and other natural resources. Officials from resource-rich regions have long complained that the vast majority of the benefits from these assets have flowed away from their regions to the national government and to private sector companies closely associated with decision-makers in Jakarta. While the New Order government kept a tight lid on calls for greater regional autonomy and regional control over natural resource revenues, the post-Soeharto government has not been able to ignore these demands. On the contrary, since 1998 the country's senior leadership has recognized that its ability to maintain Indonesia's integrity as a nation may ultimately depend on its capacity to strike a more equitable balance of power between the national government, on the one hand, and the provincial and district governments, on the other.

Over the last three years, the national government has issued several important pieces of legislation aimed at transferring authority to the provincial and district governments, and at allowing resource-rich regions to retain a larger share of the fiscal revenues generated within their jurisdictions. The most significant of these have been Law 22 on Regional Governance and Law 25 on Fiscal Balancing, both of which were issued in May 1999. Together, these laws provide the legal basis for regional autonomy, laying out a broad framework for the decentralisation of administrative and regulatory authority primarily to the district level. These laws have been supported by a variety of implementing regulations and sector-specific decentralisation laws, including Law 41 of 1999, a revised version of Indonesia's Basic Forestry Law, which outlines the division of administrative authority in the forestry sector under regional autonomy.

In many parts of Indonesia, provincial and district officials acting in the spirit of regional autonomy have instituted reforms that extend well beyond 
the authority granted to them under the national government's decentralisation laws and regulations. Indeed, the formal decentralisation process has been driven, to a significant degree, not by policy decisions made at the national level but, rather, by decisions made by provincial and district level actors. This process has often been ad hoc in nature, with national policymakers frequently finding themselves in the position of having to react to fast-moving changes that have occurred in the provinces and districts. Far from being a well-planned and carefully-managed exercise in bureaucratic reorganization, the implementation of regional autonomy in Indonesia has been characterized by intense struggles among the different levels of government, each of which represents a competing set of political and economic interests. In this way, regional autonomy has stretched well beyond the formal decentralisation of administrative and regulatory authority; in practice, it also involves a significant, if largely informal and unplanned, devolution of power from the national government to its provincial and district-level counterparts.

The formal and informal processes of decentralisation have been accompanied by a wide-ranging set of governance and economic reforms, collectively known as reformasi, that are associated with Indonesia's transition away from Soeharto's New Order regime. Broadly defined, reformasi refers to the transformation and dismantling of the policies, practices, and institutional structures through which the New Order leadership and a handful of well-connected conglomerates controlled the political and economic life of the country prior to Soeharto's resignation in May 1998. While significant elements of the reformasi agenda coincide with the changes occurring under regional autonomy, these reform processes are also quite distinct. Whereas reformasi refers to a shift away from the constellation of interests and power structures that have supported a particular regime, decentralisation and regional autonomy refer to the transfer of authority from the national government to Indonesia's provincial and district governments.

\section{Decentralisation of Forest Administration}

The formal and informal processes of decentralisation that are now occurring in Indonesia have far-reaching implications for forest management and for the livelihoods of communities living in and around forested areas. On the positive side, experience from other countries suggests that decentralised systems of forest management often lead to more sustainable and equitable use of these resources, as decision-makers are physically located closer to where their policies will be implemented (Conyers 1981; Rondinelli, Nellis, and Cheema 1983). This proximity often brings with it improved understanding of the specific biophysical, social, and institutional conditions influencing forest management at the field level; better capacity to monitor the activities of forest user groups; and greater access to local knowledge about the management and utilization of forest resources -- which are sometimes highly specific to particular social groups and/or ecosystems (Carney 1995).

In addition, decentralised forest administration often allows for greater participation on the part of forest communities in policy decision-making processes, and more direct accountability of policymakers to peoples whose livelihoods depend on forests 
(Brandon and Wells 1992). Decentralisation also frequently implies a more equitable distribution of benefits from forest resources, as local communities and governments in forested regions are able to secure a greater portion of revenues from the extraction of timber and other forest products (Ascher 1995; Ostrom 1990).

In addition to providing opportunities for expanded equity and improved forest management, however, decentralisation also carries significant risks. In many countries, national governments have decentralised without first creating the necessary institutional capacity at the provincial or district levels to administer forests effectively (Rivera 1996). Often, national governments assign tasks to provincial and district governments without giving them adequate resources for carrying out these tasks. Most provincial and district governments lack essential technical skills and must look to other entities for advice, training, and technical information. In cases where local elites have been strong and/or traditionally marginalized groups have been unable to organize themselves, decentralisation has often strengthened pre-existing power relations, rather than promoting democratic decision-making processes (Utting 1993). Finally, even when elite groups do not dominate provincial and district governments, it is often that case that these governments have little interest in sustainable forest management.

\section{Indonesia's Forestry Sector}

The manner in which decentralisation affects forest management, community livelihoods, and economic development is of particular significance in Indonesia due to the scale and importance of the country's forest resources. Indonesia has the world's third largest tract of tropical forests, surpassed in area only by those of Brazil and Congo. In 1997, the country's total forest cover was officially estimated to be 100 million hectares (MOFEC, cited in World Bank 2001). It has been conservatively estimated that at least 20 million people depend on Indonesia's forests for the bulk of their livelihoods (Sunderlin et al. 2000). Over the last three decades, the national government has allocated over 60 million hectares of forest to commercial logging companies, and Indonesia's forestry sector industries have long ranked second only to petroleum in terms of their contribution to GNP (Barr 2001). The forestry sector currently generates approximately US\$ 7 billion in annual revenues.

Well before the country's ongoing decentralisation process began in late-1998, Indonesia's forestry sector had entered a period of crisis. From the mid-1980s onward, deforestation is estimated to have occurred at a pace of 1.6 million hectares per year (Toha 2000). A major factor driving this high level of deforestation and associated forest degradation has been overcapacity in the nation's wood processing industries. Through the mid1990s, Indonesia's sawnwood, plywood, and pulp industries are collectively estimated to have consumed 60-80 million cubic meters $\left(\mathrm{m}^{3}\right.$ ) of wood per year (Barr 2001; Scotland et al. 1999). Log consumption on this scale has stood well above the Indonesian government's own widely-cited sustainable timber harvest threshold of 25 million $\mathrm{m}^{3}$ per year. Moreover, with few effective regulatory structures in Indonesia's forestry sector, domestic demand for timber has resulted in large volumes of wood being harvested from illegal sources (ITFMP 1999). At the same time, a decline in the nation's HPH timber concession system, coupled with rapid expansion in oil palm and other forms of 
agroindustrial plantations, has meant that a growing portion of the nation's wood supply has been obtained through clearing of natural forest rather than selective harvesting at multiple-rotation timber concessions (Barr 2001).

\section{Scope of the Present Study}

The present study examines the preliminary effects of decentralisation of forest administration in Kotawaringin Timur District, Central Kalimantan. It is one of nine district level case studies carried out during 2000 and early-2001 by the Center for International Forestry Research (CIFOR) in four provinces: Riau, East Kalimantan, Central Kalimantan, and West Kalimantan. The findings presented in these studies reflect the conditions and processes that existed in the study districts during the initial phase of Indonesia's decentralisation process.

Each of the case studies used a rapid appraisal methodology for gathering data at the district and provincial levels. For each case study, preliminary visits were made to the district and provincial capitals to establish initial contacts and to identify key issues. Second visits for data gathering were then carried out for periods of 10-14 days in each district, with shorter amounts of time in the provincial capitals. The collection of primary data involved semi-structured interviews with key informants, including: government officials; forest industry actors; members of communities living in and around forests; political party representatives; officers from the regional military and police force; informal district leaders; representatives from nongovernmental organizations (NGOs); university researchers; and individuals involved with donor agencies and development projects. Data collection also involved the review of primary and secondary documents, including: district and provincial laws and regulations; government statistics; regional news media articles; industry publications; research studies; and reports prepared by NGOs and donor agencies.

Each of the project's case studies has been structured to focus on processes that have occurred at the district and, to a lesser extent, the provincial levels. To avoid repetition, more general information on the history of forest administration and forestry sector development in Indonesia, as well as significant national policy and legal-regulatory reforms associated with decentralisation, has been placed in an accompanying report which synthesizes the project's major findings. Readers are encouraged to review the case studies in conjunction with this synthesis in order to appreciate the broader historical and policy contexts within which the district and provincial decentralisation processes are now occurring.

Christopher Barr and Ida Aju Pradnja Resosudarmo

Bogor, Indonesia 


\section{Glossary}

AMDAL

APBD

Balai Konservasi Sumber Daya Alam

Bank Pemodalan Daerah

BAPPEDA

\section{BAPPENAS}

BKSDA

BPN

BPS

BUMD

Bupati

CDC

CDK

CIFOR

$\mathrm{CPO}$

Dana Pembinaan Usaha Kecil Koperasi

DFID

Dinas Kehutanan

Dinas Kehutanan Tingkat II

Dinas Perkebunan

Dinas Perkebunan Tingkat II

DR

GTZ

HGU

$\mathrm{HPH}$

HPHKm

Hutan Lindung

IHH

IPK
Analisis Mengenai Dampak Lingkungan, Environmental Impact Assessment

Anggaran Pendapatan dan Belanja Daerah, Regional Income and Budget

Natural Resource Conservation Office

Regional Capital Bank

Badan Perencanaan Pembangunan Daerah, Regional Development Planning Agency

Badan Perencanaan Pembangunan Nasional, National Development Planning Board

Balai Konservasi Sumber Daya Alam, Natural Resource Conservation Office

Badan Pertanahan Negara, National Land Agency Badan Pusat Statistik, Central Statistical Agency

Badan Usaha Milik Daerah, District GovernmentOwned Companies

District Head

Commonwealth Development Corporation

Cabang Dinas Kehutanan, Branch Office of the Provincial Forestry Service

Center for International Forestry Research

Crude Palm Oil

Cooperative and Small Industry Creation Funds

Department for International Development

Provincial Forestry Service

District Forestry Service

Provincial Estate Crop Service

District Estate Crop Service

Dana Reboisasi, Reforestation Fund

Gesellschaft fuer Technische Zusammenarbeit

Hak Guna Usaha, Land Use Rights

Hak Pengusahaan Hutan, Commercial Forestry Concession

Hak Pengusahaan Hutan Kemasyarakatan, Community Forestry Concession

Protected Forest

Iuran Hasil Hutan, Forest Product Royalty

Izin Pemanfaatan Kayu, Timber Clearance Permit 
Izin lokasi

Izin prinsip

JICA

Kabupaten

Kaharingan

Kanwilhutbun

Kecamatan

NGO

PAD

Pemda

Perda

PMA

PMDH

PSDH

Reformasi

RTRWP

Surat Keterangan Lunas

TGHK

Tim Pelayanan Terpadu

Wakil Bupati

WALHI
A location permit

A principal approval permit

Japanese International Cooperation Agency

District

Animist religion

Kantor Wilayah Kehutanan dan Perkebunan, Provincial Office of the National Forest and Estate Crop Department

Subdistrict

Non Governmental Organization

Pendapatan Asli Daerah, Regionally Generated Revenues, often refers to revenues that district governments obtain from sources within their districts

Pemerintah Daerah, District Government

Peraturan Daerah, Regional Government Regulation

Penanaman Modal Asing, Foreign-Owned Investment Company

Pembinaan Masyarakat Desa Hutan, Creation of Community Forestry

Provisi Sumber Daya Hutan, Forest Resource Rent Provision

Reform process aimed at dismantling the political and economic structures of Indonesia's New Order regime

Rencana Tata Ruang Wilayah Propinsi, Provincial Spatial Plan

Prove of payment

Tata Guna Hutan Kesepakatan, Forest Land Use Concensus

Integrated Service Team

Vice District Head

Wahana Lingkungan Hidup Indonesia, Indonesian Forum for Environment 


\section{Table of Contents}

Decentralisation and Forests in Indonesia: An Overview of the Study iii Acknowledgements and Disclaimer iii Editor's Preface v Glossary $\quad$ ix

Abstract xiii

1 Background 1

1.1 Economy 4

1.2 Forest Resources 4

1.3 Large-Scale Plantations 5

1.3.1 The 'Upland Ecological Development Corridor' $\quad 6$

2 Decentralisation and Its Impact on Forests in Kotawaringin Timur District

2.1 Creating a District Regulatory Regime to Exploit Forest Resources 10

2.1.1 District Regulation No. 14 on Illegal Logging 10

2.1.2 District Regulation No. 20 on Increased

Responsibilities for the Kotawaringin Timur Forestry Service and Estate Crop Department 13

2.2 Seizing Control of Kotawaringin Timur's Forest Sector $\quad 15$

2.3 Seizing Revenue from the Provincial and National Governments $\quad 15$

2.4 Discussion 16

3. Decentralisation and Protected Area Management in Kotawaringin Timur District 18

3.1 Illegal Logging in Kotawaringin Timur's National Parks 20

4. Decentralisation and the Oil Palm Subsector in Kotawaringin Timur District $\quad 21$

4.1 Oil Palm Development in the Danau Sembuluh Area 22 4.1.1 PT Agro Indomas 22

4.2 Oil Palm Production in an Era of Regional Autonomy and Considerable Change 25

5 Conclusion 28

Postscript $\quad 29$

Endnotes $\quad 30$

References 32

Appendix A. HPH in Kotawaringin Timur District, 2000

Appendix B. Applications for Oil Palm Developments and the Release of Forest Land in Kotawaringin Timur District, $2000 \quad 36$ 


\section{List of Tables}

Table 1. Area and Population of Subdistricts in Kotawaringin Timur, 1998

Table 2. Revenue Generated from Central Kalimantan's Mining, Forestry and Plantation Sectors, by District/Municipality, 1994/95-1998/99

Table 3. Log and Processed Timber Production from Central Kalimantan (1998/99)

Table 4. Potential Oil Palm Developments in Kotawaringin Timur, 2000

Table 5. Tariffs Charged to Illegal and Legal Carriers of Timber in Kotawaringin Timur District

Table 6. Revenue Generated by Taxing Illegal Timber Carriers (April-June 2000)

Table 7. Total Log Production in Kotawaringin Timur, 2000

Table 8. Estimated Revenue Generated within Kotawaringin Timur, 2000

\section{List of Maps}

Map 1. Kotawaringin Timur District

Map 2. Planned 'upland ecological development corridor' for Central Kalimantan

Map 3. Plantation Estates Surrounding Tanjung Puting National Park

Map 4. Designated Plantation Locations in the Danau Sembuluh Area

\section{List of Figures}

Figure 1. Oil Palm Area Growth in Central Kalimantan (1994-1997) 7

Figure 2. District Income in Kotawaringin Timur (1995-2000) 10

Figure 3. Growth of Private Oil Palm Estates in Central Kalimantan $(1996-2000)$

\section{List of Photos}

Photo 1. Illegal Sawmills Operating in Kotawaringin Timur 


\section{Abstract}

Kotawaringin Timur district lies within the Dayak heartland of Central Borneo. Prior to the late 1960 s, most of the district was covered in dense tropical forest. However, these forests have been increasingly exploited since the 1970s when former-president Soeharto granted large timber concessions to logging companies in the area. Although Kotawaringin Timur's forests still supply 49 percent of Central Kalimantan's log production and half of its sawn timber and moulding, its forest resources are close to being exhausted. The rate of deforestation and forest degration in the area is also increasing as the illegal logging trade takes hold. By 2000 , around $511,823 \mathrm{~m}^{3}$ of meranti logs, or close to half of the district's official log production, were 'illegally' harvested in the district.

In the era of regional autonomy, the Kotawaringin Timur government is increasingly relying on the district's forest resources for income. In doing so, it has effectively legalised and legitimised illegal logging in the district and wrested much of the revenues obtained from large-scale logging from the provincial and central governments. For example, the district government was able to generate an estimated US\$ 6.2 million from the natural resource sector in 2000. More than half of this revenue was obtained from the illegal logging trade alone.

As Kotawaringin Timur's forest resources decline, the district government hopes to generate income from the plantation sector - particularly the oil palm subsector. This paper examines the status of forest resources in Kotawaringin Timur and details some of the changes resulting from the new decentralisation laws released by the Habibie government in 1999. It also examines the status of the oil palm subsector in the district and explores some of the challenges that the subsector faces in an era of economic and political change.

This study was commissioned by the Center for International Forestry Research (CIFOR) in 2000. It was one of nine studies organized by CIFOR to examine the potential impact of Indonesia's planned decentralisation programme in forest-rich districts. Fieldwork for this study was undertaken in 2000. Numerous changes have undoubtedly occurred since the decentralisation laws came into effect in January 2001 and ethnic violence broke out in the district in February 2001. Continuing violence in the district will inevitably deter investors in the oil palm subsector. 


\section{BACKGROUND}

Kotawaringin Timur is the largest district (kabupaten) in Central Kalimantan (Map 1). It has a land area of 50,600 square kilometres $\left(\mathrm{km}^{2}\right)$ - that is, 31 percent of the total land area of Central Kalimantan province, or 9 percent of the total land area of Kalimantan (or Indonesian Borneo) (BAPPEDA and BPS 1998). The district consists of 24 subdistricts (kecamatan) and two assistant regions (wilayah pembantu) attached to the district head, or Bupati. Because Kotawaringin Timur is so large, these two assistant regions-Seruyan and Katinigan-exist to help manage the district's resources, monitor activities and collect data. The three main administrative regions are determined by the three main river systems in the region: the Katingan, Mentaya and Seruyan Rivers. In fact, the entire spatial structure of the region is based on these three river systems, and most of the existing patterns of human settlement and land use have been formed along rivers and streams. The present towns with local and regional trading functions are located at the confluence points of rivers.

Despite being Central Kalimantan's largest district in terms of total land area, Kotawaringin Timur is the province's second most populated district after Kapuas. While official statistics are likely to underestimate the population of the district, the local government estimates that there are close to 500,000 people living in the region (Table 1). Most of Kotawaringin Timur's inhabitants live in the subdistricts of Mentaya Baru Ketapang, Mentaya Hulu, Baamang and Mentaya Hilir Selatan. The Mentaya River runs through all three of these subdistricts. Subdistricts in the far reaches of the district (such as Katingan Hulu, Seruyan Hulu, Marikit and Senaman Mantikei) are difficult to access and have low population levels. Because much of the district is difficult to access, few scholars have visited the area and relatively little has been written about it (Mubyarto and Baswir 1989).

Although there are no official records of the ethnic distribution of Kotawaringin Timur's inhabitants, the Dayak population is primarily composed of: the Ngaju, who are a relatively recent conglomeration of related groups living on Kotawaringin Timur's three main rivers; the Tamoan, who are primarily found in the Sampit area; and the Danum, who primarily reside in the upper watershed areas (Sellato 2001). The Ngaju are a group that federated in the 1950s for political reasons (to wrest from Soekarno the creation of a province of their own, autonomous from Banjarmasin). The Ngaju, originally meaning 'upriver', is the largest Dayak group in Central Kalimantan (Sellato 2001). They are also the most active politically, and have long been powerful enough to stand up to the central government (Sellato 2001). For instance, the Ngaju Dayaks were instrumental in obtaining legal recognition of the animist religion (Kaharingan) from the central government in 1980 (Brookfield et al. 1995).

In addition to the Dayak people, Malay, Chinese, Javanese and Madurese people can be found in the district. The largest migrant population is thought to be the Malays, followed by the Chinese, Javanese and Madurese (JICA and BAPPENAS 1999a). According to King 

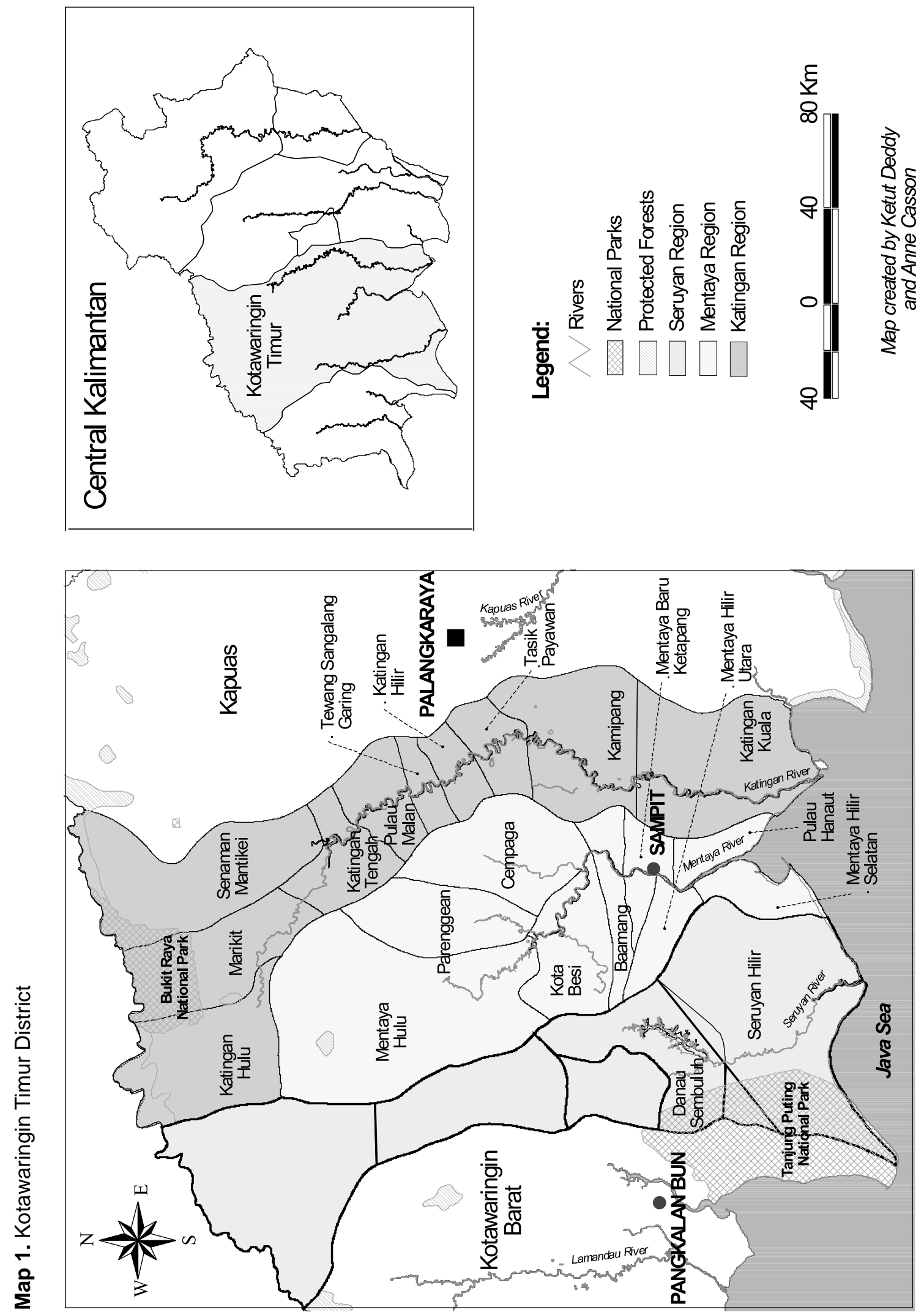
Table 1. Area and Population of Subdistricts in Kotawaringin Timur, 1998

\begin{tabular}{|c|c|c|c|c|c|}
\hline No. & Subdistrict & Capital City & $\begin{array}{l}\text { Area } \\
\left(\mathrm{km}^{2}\right)\end{array}$ & $\begin{array}{c}\% \text { Area } \\
\text { Kotawaringin } \\
\text { Timur }\end{array}$ & Population \\
\hline 1 & Mentaya Hulu & Kuala Kuayan & 6,255 & 12.54 & 45,412 \\
\hline 2 & Seruyan Hilir & Kuala Pembuang & 6,087 & 12.10 & 21,130 \\
\hline 3 & Seruyan Hulu & Tumbang Manjul & 4,746 & 9.36 & 8,964 \\
\hline 4 & Katingan Kuala & Pegatan & 3,266 & 6.44 & 28,716 \\
\hline 5 & Senaman Mantikei & Tumbang Kaman & 3,030 & 5.98 & 12,376 \\
\hline 6 & Kamipang & Baun Bango & 2,793 & 5.51 & 7,843 \\
\hline 7 & Katingan Hulu & Tumbang Senamang & 2,604 & 5.14 & 10,105 \\
\hline 8 & Danau Sembuluh & Telaga Pulang & 2,424 & 4.78 & 7,762 \\
\hline 9 & Cempaga & Cempaka Mulia & 2,424 & 4.78 & 24,100 \\
\hline 10 & Marikit & Tumbang Hiran & 2,178 & 4.30 & 5,757 \\
\hline 11 & Kota Besi & Kota Besi & 2,177 & 4.29 & 21,759 \\
\hline 12 & Seruyan Tengah & Rantau Pulut & 2,012 & 3.97 & 24,511 \\
\hline 13 & Parenggean & Parenggean & 1,774 & 3.50 & 18,720 \\
\hline 14 & Hanau & Pembuang Hulu & 1,135 & 2.24 & 10,772 \\
\hline 15 & Katingan Tengah & Tumbang Samba & 1,089 & 2.16 & 15,648 \\
\hline 16 & Mentaya Hilir Selatan & Samuda & 928 & 1.83 & 31,214 \\
\hline 17 & Pulau Malan & Buntut Bali & 805 & 1.59 & 7,451 \\
\hline 18 & Tasik Payawan & Petak Bahandang & 804 & 1.59 & 6,132 \\
\hline 19 & Baamang & Baamang & 774 & 1.53 & 36,042 \\
\hline 20 & Mentaya Hilir Utara & Bagendang & 723 & 1.43 & 8,642 \\
\hline 21 & Mentaya Baru Ketapang & Sampit & 722 & 1.42 & 68,531 \\
\hline 22 & Katingan Hilir & Kasongan & 663 & 1.31 & 12,866 \\
\hline 23 & Pulau Hanaut & Bapinang & 619 & 1.22 & 20,315 \\
\hline \multirow[t]{2}{*}{24} & Tewang Sg. Garing & Pendahara & 568 & 1.12 & 8,682 \\
\hline & Total & & 50,600 & 100 & 463,450 \\
\hline
\end{tabular}

Source: BAPPEDA and BPS (1998).

(1993), the Malay population has been augmented by Muslim outsiders from Java, Sumatra, Sulawesi and the Malayan Peninsula. Some Malay communities also owe their establishment to the early immigration of Muslim traders from western parts of the archipelago. Malays live primarily off smallscale trade, sea and inland fishing, rice agriculture (usually swamp rice cultivation), coastal gathering and, more recently, commercial agriculture (BAPPEDA and BPS 1998). In recent years, large numbers of Malay people have also been coming to the district from Banjarmasin, South Kalimantan, to work in illegal sawmills.
As with the Malay settlement, Javanese and Madurese settlement dates back to the fourteenth and fifteenth centuries when the East Javanese kingdom of Majapahit extended over some parts of Borneo (King 1993). However, larger numbers of Javanese and Madurese people have come to Kotawaringin Timur since the 1970s as part of the Soeharto government's transmigration programme ${ }^{2}$. Both the Javanese and the Madurese tend to dwell in towns and work as casual labourers, pedicab and taxi drivers, fishermen and estate workers (King 1993). The Chinese can primarily be found in the trade and commercial sectors. However, they are also heavily involved in the district's timber industry. When fieldwork for this study was 
carried out, most of the middlemen engaged in the illegal logging trade in Kotawaringin Timur were of Chinese origin.

\subsection{ECONOMY}

Kotawaringin Timur is an extremely wealthy region in terms of its natural resource potential; however, the district's physical infrastructure and industrial facilities are limited, and most of its inhabitants have subsistence livelihoods. The region has one asphalt road that runs through Sampit connecting Pangkalanbun (the capital city of Kotawaringin Barat district) to Palangkaraya (the capital city of Central Kalimantan). The road is in poor condition due to heavy traffic from logging trucks. While most of the villages in Kotawaringin Timur are extremely poor, Sampitthe capital city of Kotawaringin Timur-has some infrastructure. For instance, the capital city hosts a small airport where a daily flight passes through Sampit from Palangkaraya to Pangkalanbun. All of the government offices have been moved to new offices on the road connecting Sampit to Pangkalanbun. Although recently built, these offices are very basic and only a few have computers or resources. Many of the employees who staff these offices have limited skills and minimal education.

Kotawaringin Timur's local economy largely revolves around the timber industry. In contrast to many districts in the province of East Kalimantan, no oil exists in Kotawaringin Timur or in any other district in Central Kalimantan (Mubyarto and Baswir 1989). This is evidenced by the amount of revenue generated from various resource sectors from 1994 to 1999 (Table 2). Over this period, approximately US $\$ 1.9$ million $^{3}$ was generated through the forest sector in Kotawaringin Timur, while approximately US $\$ 500,000$ was received through the mining sector. The only other district to rely heavily on the forest sector for district income was Barito Utara, which generated approximately US $\$ 1.3$ million. While the plantation sector only generated US $\$ 110,000$ in Kotawaringin Timur, the only district to generate more income from this sector was Kotawaringin Barat, which received US $\$ 130,000$. The Kotawaringin Timur government is optimistic that it will increase revenue from this sector in the near future. District reliance on the forest and plantation sectors for district income will be discussed in further detail below.

\subsection{FOREST RESOURCES}

According to Central Kalimantan's latest 'reconciled land-use plan' or paduserasi RTRWP $^{4}, 2.7$ million hectares of Kotawaringin Timur are classified as forest lands. Of this total, 488,170 hectares are classified as 'Protected Forest' (including two national parks-Tanjung Puting and Bukit Raya), 275,200 hectares are 'Limited Production Forest', 451,100 hectares as 'Production Forest' and 439,100 hectares as "Settlement Areas'. The largest forest classification (just over one million hectares) is for 'Conversion Forest' - forest area designated for conversion to estate crops such as oil palm (BAPPEDA and BPS 1998). That a significant portion of forest has been designated as

Table 2. Revenue Generated from Central Kalimantan's Mining, Forestry and Plantation Sectors, by District/Municipality, 1994/95-1998/99

\begin{tabular}{lrrr}
\hline $\begin{array}{l}\text { District/ } \\
\text { Municipality }\end{array}$ & $\begin{array}{r}\text { Forestry } \\
\text { (Rp ‘000) }\end{array}$ & $\begin{array}{c}\text { Mining } \\
\text { (Rp `000) }\end{array}$ & $\begin{array}{c}\text { Plantation } \\
\text { (Rp `000) }\end{array}$ \\
\hline Kotawaringin Barat & $6,503,018$ & $3,274,935$ & $1,301,573$ \\
Kotawaringin Timur & $19,092,946$ & $4,936,222$ & $1,109,333$ \\
Kapuas & $9,110,102$ & $6,688,494$ & 10,000 \\
Barito Selatan & $3,945,720$ & $23,598,429$ & 84,882 \\
Barito Utara & $13,871,152$ & $13,656,679$ & 10,000 \\
Palangkaraya & $2,768,918$ & $3,065,001$ & - \\
\hline
\end{tabular}

Source: BPS and BAPPEDA (1998). 
“Conversion Forest' indicates an increasing awareness of the depletion of Kotawaringin Timur's forest resources. It also reflects the local government's enthusiasm for developing plantation estates.

Large-scale cutting of timber in Kotawaringin Timur began in the early 1970s when Indonesian forests were declared the property of the state and the New Order regime opened the forests of the 'outer islands' to largescale timber extraction (Potter 1990; Barr 2001). The Soeharto government awarded generous timber concessions to foreign companies eager to exploit the vast stands of tropical hardwoods in the area. The most valuable timber species were ironwood Eusideroxylon zwageri, and a number of dipterocarps, including meranti Shorea spp., merawan Hopea spp., kapur Dryobalanops spp., kruing Dipterocarps spp. and ramin Gonystylus bancanus. These resources have been exploited very heavily; for example, ramin can now only be found primarily in the swamp forests of Tanjung Puting National Park (JICA and BAPPENAS 1999b).

In 1999, Central Kalimantan's Provincial Forestry Service (Dinas Kehutanan) monitored forestry activities in Kotawaringin Timur through four branch offices (Cabang Dinas Kehutanan, or CDK) - Seruyan, Kotawaringin Timur, Katingan Hilir and Katingan Hulu. According to these four branch offices, approximately 49 percent of Central Kalimantan's log production came from Kotawaringin Timur in 1998/99 (Departemen Kehutanan dan Perkebunan 1999)Most of this timber came from the Seruyan region, which accounted for 30 percent of Central Kalimantan's total log production in 1998/99. Moreover, while 78 percent of the province's plywood production came from Kotawaringin Barat in 1998/99, Kotawaringin Timur produced more than half of Central Kalimantan's sawn timber and moulding, as well as 100 percent of Central Kalimantan's veneer products (Table 3 ).

In 2000, there were 40 active large-scale timber concessions (Hak Pengusahaan Hutan, or HPH) in Kotawaringin Timur, covering a total area of approximately 4.2 million hectares (Appendix A). Inhutani III-a state-owned forestry enterprise-was particularly active in the region and had access to approximately 1.3 million hectares of forest land. The largest Inhutani III concession fell within the Mentaya Hulu subdistrict and spanned a total area of 715,000 hectares. The remaining Inhutani III concessions primarily fell within the subdistricts of Katingan Hilir and Katingan Hulu (Departemen Kehutanan dan Perkebunan 1999).

Over the last 30 years, vast quantities of timber have come out of Kotawaringin Timur, and large areas of land are now infested with Imperata grasslands (alang-alang). Most of the timber from the district is now obtained from the upper watershed areas because forest land in the more accessible lowland areas has already been exhausted. As valuable tropical timber species become more difficult to find, official statistics show a decline in timber production. Data from the Kotawaringin Timur branch office of Central Kalimantan's Provincial Forestry Service (Cabang Dinas Kehutanan TK II Kotawaringin Timur) show that $\log$ production from HPHs operating in the region declined to almost half between 1996 and 1999 (Dinas Kehutanan 1999). A report prepared by the International Development Center of Japan predicted that production from timber concessions would decline by 30 percent between 1998 and 2003 (JICA and BAPPENAS 1998). Although these statistics do not take into account the recent rise in illegal logging, they do illustrate the fact that timber supplies are being depleted. In fact, a World Bank study released in 2000 predicted that most of the lowland forests in areas such as Kotawaringin Timur would be exhausted by 2010 (Holmes 2000).

\subsection{LARGE-SCALE PLANTATIONS}

Kotawaringin Timur is in a process of transition from an economy based on the timber industry to an economy structured around large-scale plantation cultivation. While the district's economy still depends significantly on natural timber resources, these resources are close to being exhausted. In the near future, Kotawaringin Timur will no longer be able to provide such a large volume of raw materials to timber-processing industries, nor will it be able 
Table 3. Log and Processed Timber Production from Central Kalimantan (1998/99)

\begin{tabular}{|c|c|c|c|c|c|c|}
\hline \multicolumn{3}{|c|}{$\begin{array}{l}\text { Log Production from Large-Scale Timber } \\
\text { Concessions or HPHs (1998/99) }\end{array}$} & \multicolumn{4}{|c|}{ Processed Timber Production 1998/99 } \\
\hline Branch Offices of Central & Area & & Plywood & Sawntimber & Moulding & Total \\
\hline Forestry Service & & $\left(m^{3}\right)$ & \multicolumn{4}{|c|}{$\left(m^{3}\right)$} \\
\hline Kotawaringin Barat & 4,978 & 184,893 & 460,731 & 47,468 & 25,061 & 533,260 \\
\hline Seruyan & 13,297 & 779,775 & 0 & 12,565 & 945 & 13,510 \\
\hline Dinas Kehutanan TK II Kotim & 5,145 & 259,878 & 70,551 & 87,994 & 43,729 & 202,274 \\
\hline Katingan Hilir & 3,345 & 73,675 & 0 & 12,899 & 5,360 & 18,259 \\
\hline Katingan Hulu & 4,353 & 146,252 & 0 & 65 & 0 & 65 \\
\hline Karayan & 7,668 & 263,723 & 30,316 & 27,382 & 13,479 & 71,177 \\
\hline Kapuas & 2,727 & 118,670 & 30,570 & 19,395 & 3,519 & 53,484 \\
\hline Barito Hilir & 2,516 & 127,677 & 0 & 5,768 & 755 & 6,523 \\
\hline Barito Tengah & 2,516 & 138,522 & 0 & 347 & 0 & 347 \\
\hline Barito Hulu & 13,644 & 492,913 & 0 & 0 & 0 & 0 \\
\hline Total & 60,189 & $2,585,978$ & 592,168 & 213,883 & 92,848 & 898,899 \\
\hline
\end{tabular}

Source: Departemen Kehutanan dan Perkebunan (1999).

to support as much direct and indirect employment as it did in the 1980s and the early 1990s (JICA and BAPPENAS 1998).

Most of the plantation estates within Central Kalimantan are oil palm estates. In fact, the oil palm subsector rapidly expanded in the four years leading up to the 1997 economic crisis. All of this growth has occurred, or been associated with, the private sector. For instance, between 1994 and 1997 oil palm area on private estates expanded from 10,987 hectares in the year 1994 to 52,595 hectares in 1997 . The smallholder sector, which is often linked to the private estate sector through transmigration programmes, also increased from 3,218 hectares in 1994 to 10,641 hectares in 1997. No government oil palm estates have been developed in Central Kalimantan (Figure 1).

Whereas most of these estates have been developed in Kotawaringin Barat (94,147 ha), 51,909 hectares of estate crops have been planted in Kotawaringin Timur. Far more location permits ( 1.3 million ha) have been released for Kotawaringin Timur than for other districts in Central Kalimantan, including Kotawaringin Barat (761,565 ha). Similarly, more forest land has already been released in Kotawaringin Timur (220,481 ha) for plantation development (Table 4; Appendix B). According to a survey conducted by the Japanese
International Cooperation Agency (JICA), the potential for large-scale oil palm plantations in Kotawaringin Timur is considerable in the Danau Sembuluh area and in an area spanning the width of the district called 'the upland ecological development corridor' (JICA and BAPPENAS 1999b). These two areas are considered prime areas for oil palm development because they are relatively flat, the soils are suitable and population density is low (JICA and BAPPENAS 1999b). Once roads are developed, access to both areas will also be relatively easy for workers and supplies because Pangkalanbun and Sampit are nearby. Both cities have the necessary infrastructure for bringing in plantation resources and exporting palm oil. It is expected that Sampit will be the biggest crude palm oil (CPO) export center in Kalimantan within a few years (personal communication with the head of the Provincial Estate Crop office, September 2000).

\subsubsection{The 'Upland Ecological Development Corridor'}

Prior to the economic crisis, the Central Kalimantan government, with the assistance of the JICA, planned to develop an 'upland ecological development corridor' in the districts of Kotawaringin Barat and Kotawaringin Timur. The corridor, comprising 1.2 million hectares, 
Figure 1. Oil Palm Area Growth in Central Kalimantan (1994-1997)

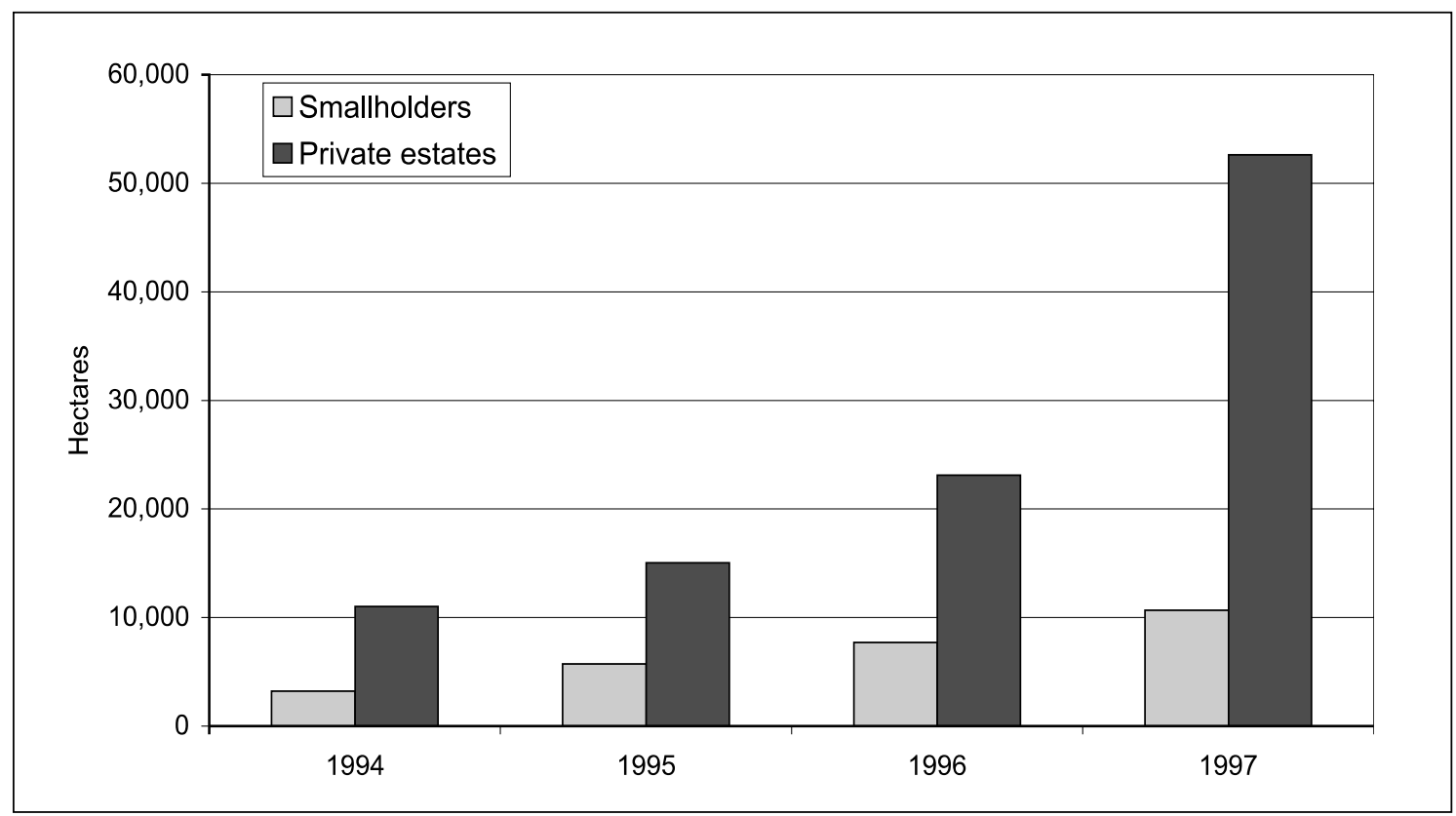

Source: Departemen Kehutanan dan Perkebunan (1996-2000).

Table 4. Potential Oil Palm Developments in Kotawaringin Timur, 2000

\begin{tabular}{lccrrr}
\hline & $\begin{array}{c}\text { Kotawaringin } \\
\text { Barat (ha) }\end{array}$ & $\begin{array}{c}\text { Kotawaringin } \\
\text { Timur (ha) }\end{array}$ & $\begin{array}{c}\text { Kapuas } \\
\text { (ha) }\end{array}$ & $\begin{array}{c}\text { Barito } \\
\text { Selatan (ha) }\end{array}$ & $\begin{array}{c}\text { Barito } \\
\text { Utara (ha) }\end{array}$ \\
\hline Location Permit & 761,565 & $1,384,483$ & 422,260 & 290,324 & 348,500 \\
Release of forest land & 110,229 & 220,481 & 16,050 & 33,600 & 28,712 \\
HGU or Land-Use Permit & 70,674 & 116,293 & 0 & 0 & 0 \\
Actual area planted & 94,147 & 51,909 & 2,732 & 13,188 & 12,768 \\
\hline
\end{tabular}

Source: Kanwil Kehutanan dan Perkebunan (2000); Badan Pusat Statistik (1998).

was specifically designed to facilitate oil palm development in the region as the designated area has high soil fertility (JICA and BAPPENAS 1999b). The corridor is quite prominent on the provincial spatial planning maps, and forestland in the corridor is clearly designated as 'Conversion Forest' for oil palm development (Map 2). In fact, the provincial government has already issued a number of permits to companies wanting to develop oil palm in the area. However, as of 2000 , little actual investment in oil palm had been realized because of the limited infrastructure in the area; no roads had yet been built. To address this problem, the provincial government's Regional Planning Agency (known as BAPPEDA) drew up plans to build an axis road running through the corridor for the transport of fresh fruit bunches to city centers such as Sampit. The road would integrate adjacent river basins in the middle stream areas. In a report on the subject, JICA said that they expected the corridor to generate a stable supply of labor for local communities and transmigration settlements and to upgrade selected subdistrict centers with improved urban services and infrastructure. However, little attention had been given to the impact the corridor would have on local people inhabiting the area or to the environmental impact caused by the development. We can, for instance, expect road development in the area to increase deforestation. Ethnic conflict will likewise increase if transmigrants are bought into the area to work on the oil palm plantations. 
Map 2. Planned 'Upland Ecological Development Corridor' for Central Kalimantan

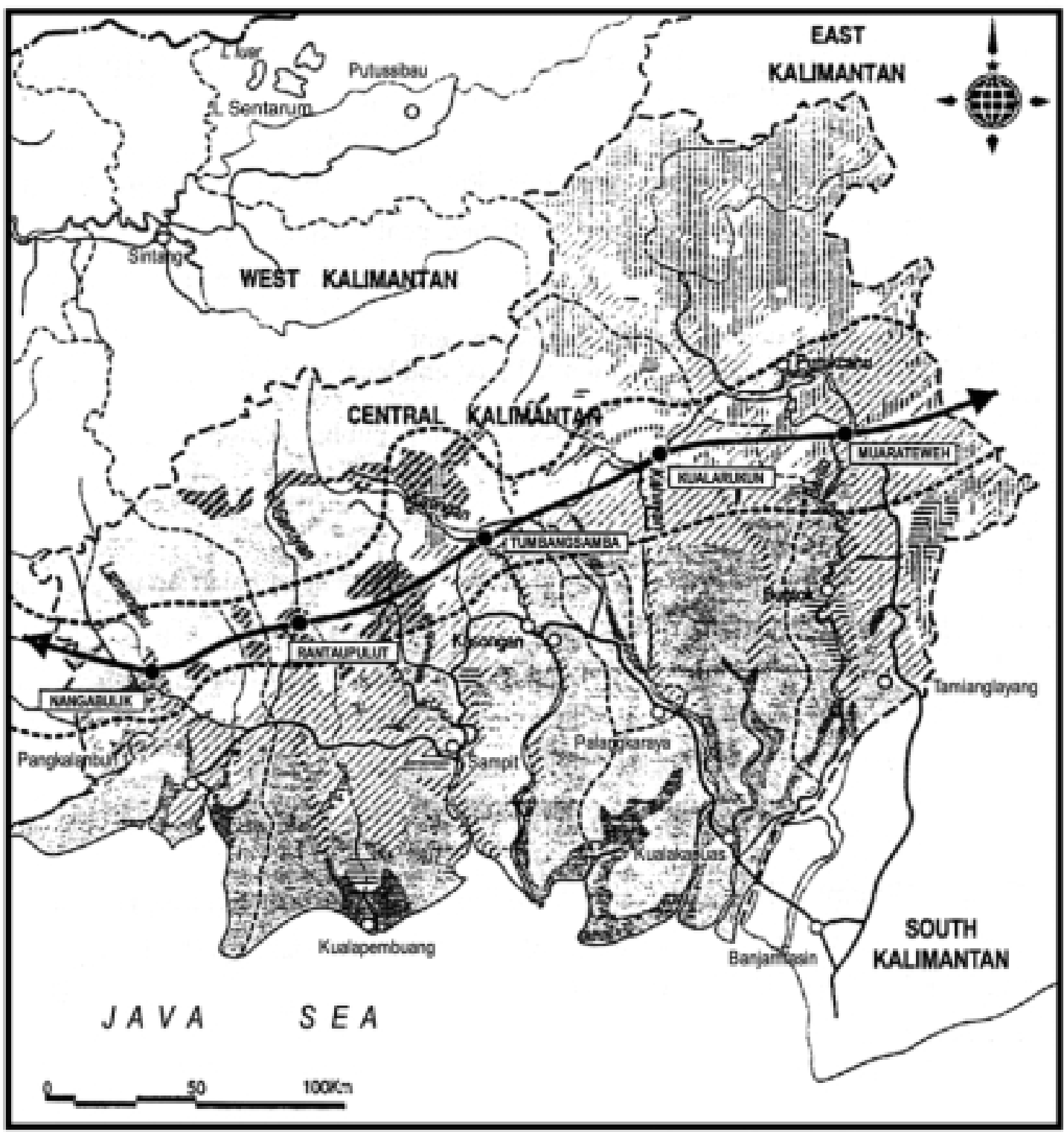

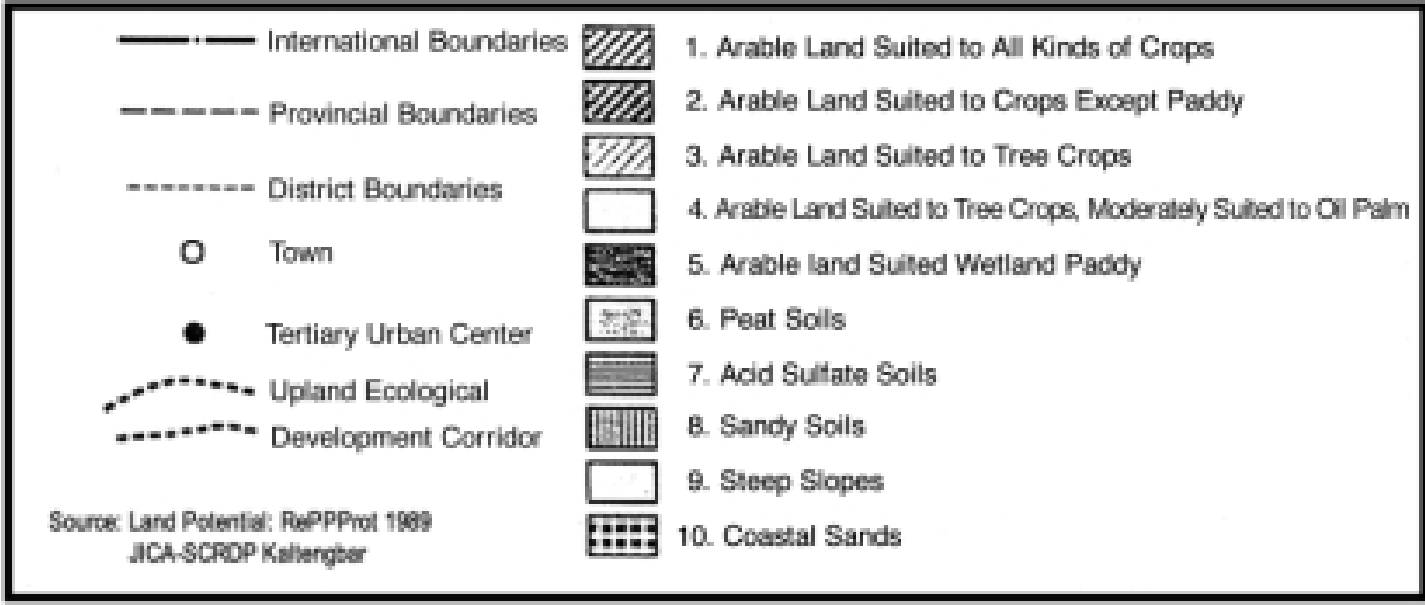

Source: JICA and BAPPENAS (1999b) 


\section{DECENTRALISATION AND ITS IMPACT ON FORESTS IN KOTAWARINGIN TIMUR DISTRICT}

In late 1999, the Central Kalimantan provincial government revealed plans to divide Kotawaringin Timur into three separate districts. This division would establish two new districts within the administrative boundaries of Kotawaringin Timur. The two new districts would originate from the two assistant administrative regions of Katingan and Seruyan, while the third district would have Sampit as its administrative center, making it the 'induk' or 'mother' district. While the decision to divide Kotawaringin Timur into three districts has been a long awaited consequence of the new decentralisation laws, there have been few moves to divide up the region. In 2000, the government's focus instead shifted to developing ways to increase the district's income from its natural resource base, primarily forest resources.

Decentralisation is not new to Kotawaringin Timur, as the district was selected in 1995 to participate in the nationwide Pilot Project for District Autonomy. Under this project, all central government offices at the district level, both from the technical departments as well as from the provincial government (Cabang and Dinas), were abolished. Their personnel, budgets, assets and responsibilities were transferred to the district governments. After negotiating with all relevant sector departments, the Minister for Administrative Reform defined a set of tasks for each of the sectors that had to be transferred to the district governments in 26 selected districts/municipalities (one in each province except for the Jakarta Special Region). Each of the selected district government received an additional grant of approximately US\$6,000 to cover the increased costs. Kotawaringin Timur was selected for this project in Central Kalimantan (JICA and BAPPENAS 1999a).

The trial decentralisation period did generate more income for the region; however, the economic crisis contributed to a subsequent decline in revenue during 1998/99 (Figure 2). For instance, in 1995/96 there was a 75 percent increase in district generated income (PAD) from US $\$ 190,000$ to US $\$ 330,000$. District income then increased another 35 percent to US $\$ 450,000$ in $1997 / 98$, but decreased by 15 percent to US $\$ 390,000$ in 1998/99.

Given the fluctuations in district income, it is not surprising that government officials at the provincial or district levels were not too optimistic about Laws 22 and 25 in March 2000. However by June 2000, government officialsspurred on by the reformasi movement that called for a change to the way in which the central government had managed (and mismanaged) district resources-had decided to take matters into their own hands. They were confident that the central government had no real intention of handing over power to the districts and were determined to seize power and revenue from it. Laws 22 and 25 had given them the means to do so.

Even though Laws 22 and 25 did not come into effect until January 2001, the Bupati of Kotawaringin Timur undertook several assertive moves in 2000 to wrest control from the central and provincial governments under the guise of regional autonomy. The Bupati of Kotawaringin 
Figure 2. District Income in Kotawaringin Timur (1995-2000)

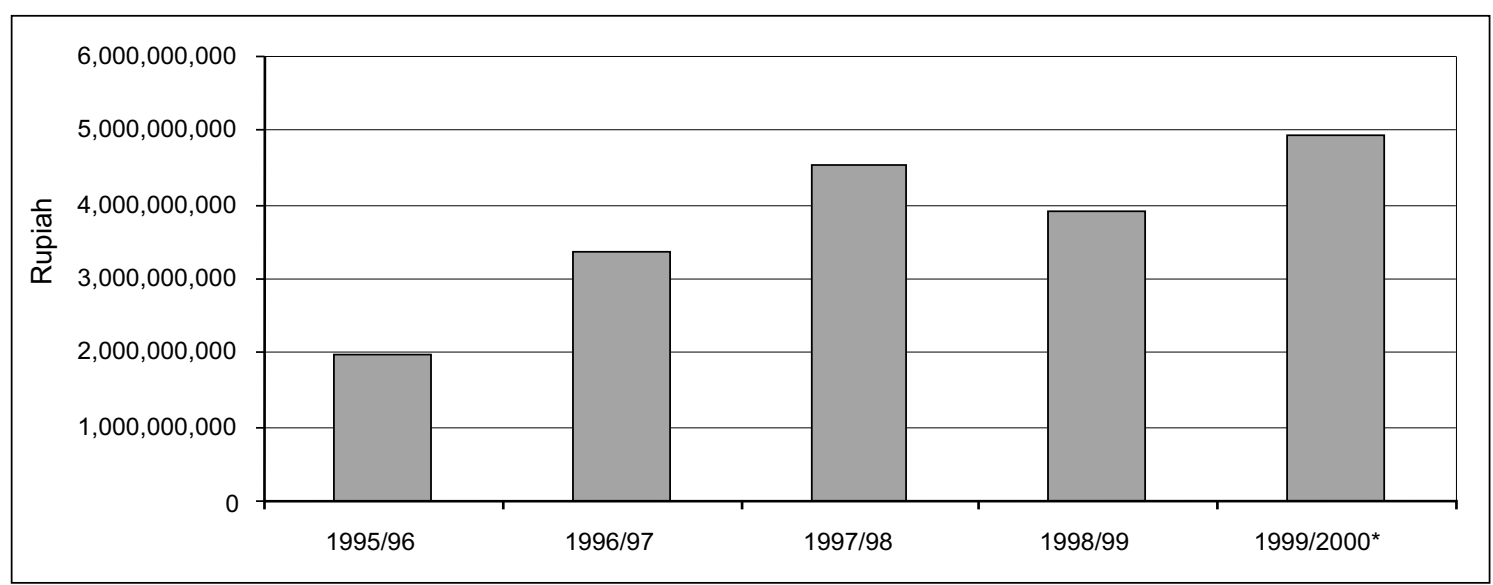

Source: Personal communications with staff from the Kotawaringan Timur finance office, 2000.

Timur was elected by the district assembly of Kotawaringin Timur in March 2000. Shortly after election, he released a mission statement entitled "The Mission and Vision of Kotawaringin Timur: Sustainable Human Development". Addressing the need for regional autonomy, the Bupati states that:

The handing down of Law No. 22/1999 and Law No. 25/1999 gives vast and concrete opportunities and responsibilities to the region in a proportional way in terms of creating regulatory mechanisms and using natural resources and income to carry out development (Anwar 2000, my translation).

The Bupati then set about devising ways to generate district income in order to facilitate regional development. The following section discusses some of the ways in which the Bupati has been able to do this and draws attention to the potential impact this may have on the district's forest resources.

\subsection{CREATING A DISTRICT REGULATORY REGIME TO EXPLOIT FOREST RESOURCES}

Shortly after his vision statement was released, the Bupati set about creating a district regulatory regime in order to generate income. By September 2000, the district government had drawn up 43 new district regulations (Perda) to address regional autonomy. Of these new Perda, 14 had already been ratified by the Kotawaringin Timur district assembly. Another 10 Perda were being ratified by the district assembly when this fieldwork was undertaken in September 2000. A number of these new Perda, specifically Perda 14 and 20, are relevant to the forestry sector and warrant further discussion below.

\subsubsection{District Regulation No.14 on Illegal Logging}

Shortly after the Bupati was elected in March 2000, he formed a special district government (Pemerintah Daerah, or Pemda) task force called the Integrated Service Team (Tim Pelayanan Terpadu). Led by the vice district head (Wakil Bupati) of Kotawaringin Timur, the team was asked to investigate illegal logging in the district and devise ways to collect revenue from illegal activities. Specifically, the team was ordered to find out how much timber was leaving the district illegally.

On 6 May 2000, the team reported that 178 ships carrying illegal timber had been found on the Mentaya River alone. These ships were carrying approximately $77,100 \mathrm{~m}^{3}$ of sawn timber. However, instead of confiscating the timber on these ships and prosecuting those responsible, the Kotawaringin Timur district assembly decided that ships carrying illegal timber would be permitted to leave ports in Kotawaringin Timur if they were carrying a paper to state that a 'contribution for forest product retribution' had been paid to the district 
income office. The letter would state whether or not they had deposited money into the Regional Capital Bank (Bank Pemodalan Daerah) in the name of Kotawaringin Timur district assembly. Ship cargoes would subsequently be checked to verify they were carrying the load stated on their letter of receipt (Surat Keterangan Lunas) when they passed through Samuda - the last exit port on the Mentaya River. The decision was supported by the governor of Central Kalimantan who agreed that the ships should be released and issued letters stating that they had paid a tax to the district government.

While most government officials agreed that the Bupati's new action had been successful in terms of generating new income for the region, the initiative did not escape criticism. In fact, the decision to tax illegal carriers faced considerable opposition from a number of parties, including provincial officials, timber buyers outside the district, environmental activists and legal concession-holders. Provincial officials voiced concerns about the environmental consequences of the new regulation, but were more worried by the fact that they had lost control of how natural resources were being managed in the district. They were anxious that the new regulation might contradict provincial and national laws and were uncertain about how much of the revenue generated would be distributed to the provincial and national levels. Most Kotawaringin Timur officials felt the district government should retain a minimum of 80 percent of the revenue generated by the Bupati's new tax, ostensibly in accordance with the new decentralisation laws. [It should be noted, however, that the provision in Law 25/1999 that 80 percent of all timber revenues should go to 'the regions' stipulated that these would be shared between the provincial and district governments]. As of July 2000, few discussions had been held with the provincial or central governments about this issue. In fact, the central government was largely being kept in the dark about the Bupati's tax on illegal timber shipments and the revenue obtained from it because the practise contradicted national law. Environmental activists and NGOs raised concerns about the environmental consequences of the new tax, emphasizing that the rate would not be high enough to cover future environmental costs incurred from illegal logging activities.

Legal concession-holders raised the most vocal opposition to the new regulation. They complained that it wouldencourage illegal logging in their concession areas and that it was unjust because it failed to acknowledge they had paid large sums of money to secure logging rights. They also objected to the tariffs that illegal carriers were charged. When the tax was first introduced, illegal carriers were charged US $\$ 12.50 / \mathrm{m}^{3}$ while legal carriers were charged approximately US $\$ 19 / \mathrm{m}^{3}$ (Table 5). Concessionholders therefore requested that the tariff be the same for both legal and illegal carriers to ensure that they were not disadvantaged by the new tax system.

Table 5. Tariffs Charged to Illegal and Legal Carriers of Timber in Kotawaringin Timur District

\begin{tabular}{|c|c|}
\hline $\begin{array}{l}\text { Original Tariff for Illegal Carriers } \\
\text { of Timber }\end{array}$ & Per $\mathrm{m}^{3}$ \\
\hline PSDH/IHPH & $\operatorname{Rp} 20,400$ \\
\hline Reforestation fund ${ }^{a}$ & US\$2 \\
\hline Regionally generated revenue (PAD) & $\operatorname{Rp} 52,200$ \\
\hline Total & $\operatorname{Rp} 125,000$ \\
\hline \multicolumn{2}{|l|}{ Current tariff for legal carriers of timber } \\
\hline $\mathrm{PSDH} / \mathrm{IHPH}$ & $\operatorname{Rp} 64,000$ \\
\hline Reforestation fund ${ }^{a}$ & US $\$ 16$ \\
\hline Total & Rp 192,000 \\
\hline \multicolumn{2}{|l|}{ New tariff for illegal carriers of timber } \\
\hline $\mathrm{PSDH} / \mathrm{IHPH}$ & $\operatorname{Rp} 40,000$ \\
\hline Reforestation fund ${ }^{a}$ & $\operatorname{Rp} 32,000$ \\
\hline Regionally generated revenue (PAD) & $\operatorname{Rp} 87,000$ \\
\hline Total & $\operatorname{Rp} 160,000$ \\
\hline
\end{tabular}

Note: a. This fund is drawn from a tax on log production to assist companies to replant logged-over forest; and is denominated in US \$.

Source: Personal communications with staff from the Kotawaringin Timur government, July 2000.

Finally, illegal timber companies and ships were concerned about the legitimacy of their activities and requested that the government of Kotawaringin Timur issue a policy or Perda to legitimise the tax illegal carriers were required to pay. The Kotawaringin Timur government responded positively to this request and decided to issue Perda 14 on retribution for logs and processed timber to legitimise the issuance of 
letters to illegal carriers stating they had paid a tax to the regional government. The tariff charged to illegal carriers was also raised from US\$12.50 to US\$16 to appease the legal concessionaires. The decision to charge illegal timber carriers was ratified by the district assembly and the governor of Central Kalimantan in late April 2000. The governor agreed to the regulation in 2 May 2000, provided that some of the revenue generated was distributed to the provincial and central government. The amount to be distributed was left to the Bupati's discretion. By September 2000, no decision had been made about how much of the revenue collected through this initiative would go to the central or provincial governments. In fact, the district government did not seem keen to give any of the revenue to the central or provincial government. This was, no doubt, causing the provincial and central governments some concern and adding fuel to their protests against the initiative.

The Bupati was able to generate a great deal of revenue through this new initiative in 2000 and this undoubtedly increased his popularity in the district. For instance, in the three months of April, May and June 2000, the Bupati was able to generate Rp 24 billion (approximately US $\$ 2.4$ million) by taxing illegal carriers of timber coming out of Kotawaringin Timur $^{5}$ (Table 6).

During this period, a total of $170,641 \mathrm{~m}^{3}$ of meranti logs were shipped out of the district 'illegally', but with the knowledge of the district government (data from Pemda Kotawaringin Timur, June 2000). When compared to the official production figures for 1998, this figure is significant. According to the Provincial Forest and Estate Crop Office $1,259,580 \mathrm{~m}^{3}$ of logs were officially produced in 1998 in Kotawaringin Timur (Table 7). In other words, the recorded volume of illegally harvested $\operatorname{logs}$ for the three-month period April-June 2000 amounts to 14 percent of the district's total legal production for that year. If we assume that the production of illegally sourced logs throughout 2000 continued at this pace, $511,923 \mathrm{~m}^{3}$ of 'illegally' harvested logs would have been shipped out of the district. This constitutes close to half of the total legal production for the same year.

The ability of the Bupati to generate income through this new tax increased his popularity and consolidated his political position in his own district. However, his decision to tax carriers of illegal timber was not immediately accepted in the districts receiving the timber. The Bupati therefore set about 'socialising' his new idea to gain support in these regions and to ensure that illegal timber coming from the region was accepted in other Indonesian ports (Kalteng Pos 2000). In mid-July 2000, a special team led by the Wakil Bupati visited various ports in Java to ensure smooth deliveries of timber to the island. Because Perda 14 is a district regulation, it needed to be socialised in the provinces

Table 6. Revenue Generated by Taxing Illegal Timber Carriers (April-June 2000)

\begin{tabular}{|c|c|c|}
\hline & $\operatorname{Rp}\left({ }^{\prime} 000\right)$ & $\operatorname{Rp}\left({ }^{\prime} 000\right)$ \\
\hline \multicolumn{3}{|l|}{ Tariff $1\left(\operatorname{Rp} 125,000 \mathrm{~m}^{3}\right)$} \\
\hline $\mathrm{PSDH} / \mathrm{DR}$ & $7,998,216$ & \\
\hline Regionally generated revenue (PAD) & $5,734,984$ & \\
\hline Total & & $13,733,200$ \\
\hline \multicolumn{3}{|l|}{ Tariff $2\left(\operatorname{Rp} 160,000 \mathrm{~m}^{3}\right)$} \\
\hline $\mathrm{PSDH} / \mathrm{DR}$ & $4,424,548$ & \\
\hline Regionally generated revenue (PAD) & $5,299,734$ & \\
\hline Total & & $9,724,282$ \\
\hline Third party contribution & & 835,284 \\
\hline Total as of 19 June 2000 & & $24,292,766$ \\
\hline For PSDH/DR & & $12,422,764$ \\
\hline For Regionally generated revenue (PAD) & & $11,034,718$ \\
\hline
\end{tabular}

Source: Personal communications with Pemda Kotawaringin Timur, June 2000 
Table 7. Total Log Production in Kotawaringin Timur, 2000

\begin{tabular}{lr}
\hline Production of logs from illegal timber sources from April-June 2000 & $170,641 \mathrm{~m}^{3}$ \\
Production of logs from illegal timber sources from July-Dec 2000 & $341,282 \mathrm{~m}^{3}$ \\
Estimated total production of logs from illegal timber sources April-Dec 2000 & $511,823 \mathrm{~m}^{3}$ \\
Official production of logs in 1998 & $1,259,580 \mathrm{~m}^{3}$ \\
Expected real log production for 2000 & $1,771,503 \mathrm{~m}^{3}$ \\
\hline
\end{tabular}

Note: $a$. This is an estimate calculated by dividing the total amount of timber to come out of the region between the months of April to June by three and then multiplying this amount by six - the remaining six months of the year.

Source: Personal communications with Kotawaringin Timur government staff, June 2000.

receiving the timber. By September 2000, the regulation had been accepted by the district government of Blitar in East Java, which had signed an agreement with the government of Kotawaringin Timur stating that they would accept the timber, but impose a levy of around US $\$ 8.50$ per $\mathrm{m}^{3}$. The regulation had not been accepted in the ports of Sunda Kelapa, Juanda and Cirebon when fieldwork was completed, but the Kotawaringin Timur government was hopeful that it would be after it had explained the Perda.

The Bupati had also spread word of the district's new scheme to other Bupati in Central Kalimantan and there was speculation that the Bupati of Kapuas and Kotawaringin Barat would follow his lead (personal communications with several district government officials, June 2000). Although it would appear that Perda 14 was gaining some recognition and acceptance in other provinces receiving the timber, it did not gain the favour of the central government. In a workshop on illegal logging in Indonesia held in Jakarta in late August 2000, the Secretary General of the Ministry of Agriculture and Forestry voiced his disapproval of Perda 14. In his view, "some Bupati's are legitimising the trade in illegal timber by issuing district regulations. This contradicts national legislation and will not be tolerated". He then went on to say that the Ministry was looking into ways to control the situation and indicated that it was considering legal action against Bupati that have issued regulations in conflict with national forestry laws. However, despite these threats, the central government has been given no authority under Law 22 to revoke district government regulations and Article 80 states that the sources of the regions' revenues shall consist of regional tax income. This has since been strengthened by the issuance of Law 34/2000 on regional taxes and regulations. This law enables local governments to create their own new taxes through Perda, provided they have the approval of the district assembly and socialise the idea within the local community ${ }^{6}$. In this regulation, the central government is only given the authority to cancel the Perda within a period of 30 days after receiving notice of it.

When interviewed in September 2000, local officials were adamant that they would continue to collect revenue from the trade in illegal timber and continue to defy the wishes of a central government that had exploited the district's forest resources for over 30 years. The only change to have occurred since the central government has taken a hard-line response against the Bupati's policies is that the district government is now more cautious about revealing revenue collected from this trade. In June 2000, the regional government was very open about how much revenue they had been able to collect. By the following September, district officials were much more cautious and indicated that special permission from the Bupati himself would be required before data concerning revenues collected from the illegal timber trade could be released.

\subsubsection{District Regulation No. 20 on Increased Responsibilities for the Kotawaringin Timur Forestry Service and Estate Crop Department}

Of the remaining 29 district regulations waiting to be ratified in mid-2000, one specifically referred to the Kotawaringin Timur Forestry Service (Dinas Kehutanan Tingkat II) and the Kotawaringin Timur Estate Crop Department 
Photo 1. Illegal Sawmills Operating in Kotawaringin Timur (Photo by Anne Casson)

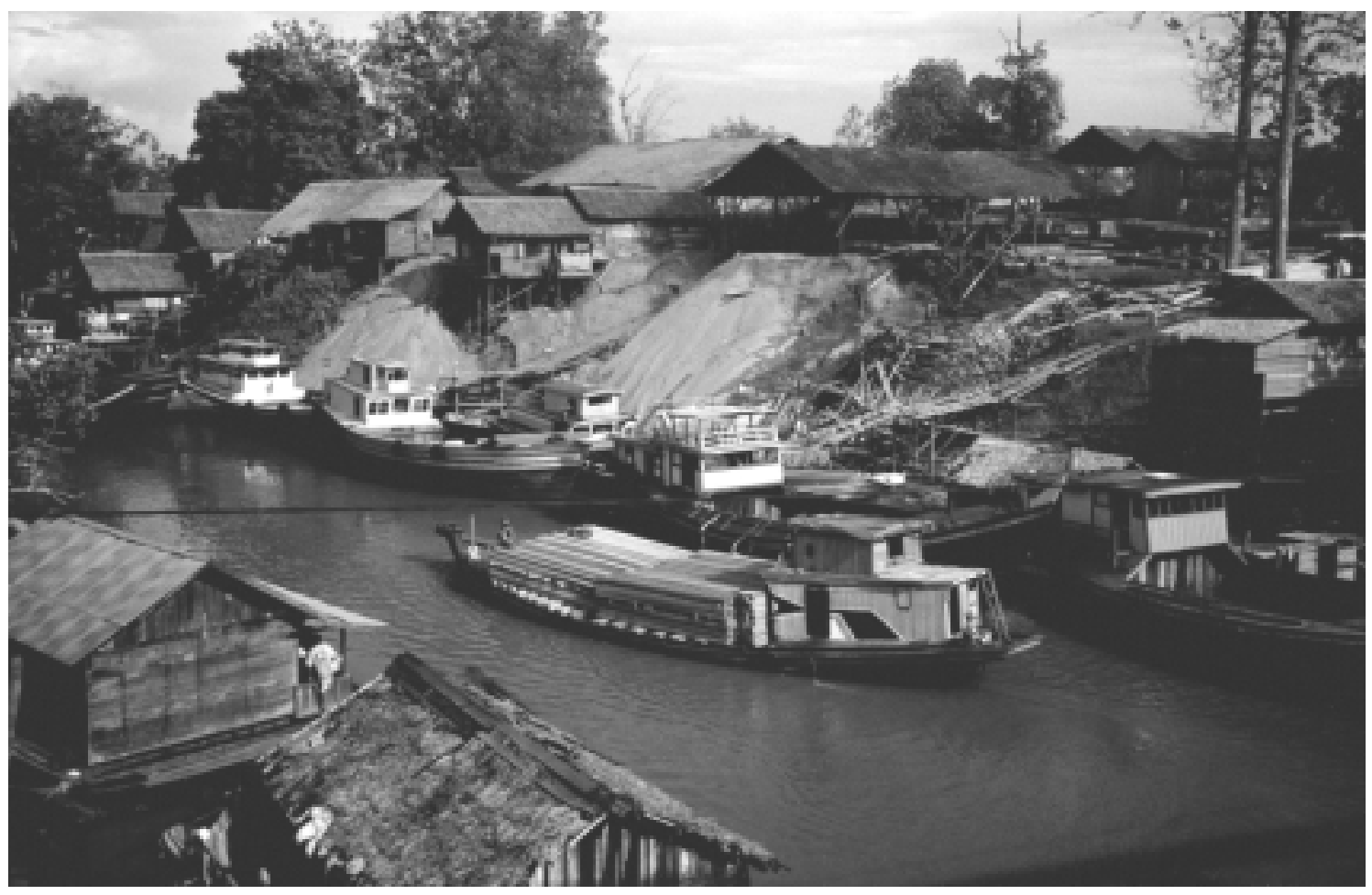

(Dinas Perkebunan Tingkat II). The draft legislation entitled: "The Organization and Work of the Kotawaringin Timur Forestry Service and Estate Crop Department", will be referred to as Perda 20 once it is ratified by the Kotawaringin Timur district assembly. The Perda effectively gives the Kotawaringin Timur Forest Service and Estate Crop Department the same authority as the national government's Regional Forest and Estate Crop Offices (Kanwil Kehutanan and Perkebunan) formerly responsible to the Ministry of Forestry and Estate Crops ${ }^{7}$. After Perda 20 has been ratified, the Kotawaringin Timur Forestry Service and Estate Crop Department will be responsible to the Bupati of Kotawaringin Timur rather than the Ministry of Forestry and Estate Crops. They will be able to formulate policy regarding the forestry sector; draw up forest and plantation maps through the spatial planning process; determine the boundaries of production forest, protected forest and plantation estates; allocate permits for the extraction of forest products; and manage protected forest areas. In addition to these responsibilities they will also be able to allocate forest-use permits.
When interviewed, staff at the Kotawaringin Timur Forestry Service and Estate Crop Department were happy with their new responsibilities, as they were confident that the district would benefit from being able to manage its own forest resources. However, they were also concerned about their capacity to carry out these new responsibilities. Although they had recently moved to new offices, the offices were greatly underresourced and the staff had very little experience, particularly in the areas of formulating forest policy, drawing up maps and determining forest boundaries. They were expecting help after the national government's Regional Office of the Forest and Estate Crop Department (Kanwil Kehutanan) is disbanded (in keeping with the regional autonomy laws) and were expecting staff from provincial government agencies to be sent to the districts. This is, however, unlikely to rectify the situation as provincial government officials usually know little more than their district counterparts. Furthermore, the process is likely to result in conflict as personnel are shifted around and some of the provincial and district officials are demoted or lose their jobs altogether. The 
provincial departments had started to initiate this process when further fieldwork for this study was conducted in September 2000.

\subsection{SEIZING CONTROL OF KOTAWARINGIN TIMUR'S FOREST SECTOR}

In addition to establishing the above regulations, the Bupati of Kotawaringin Timur held a special meeting in September 2000, to discuss how the local government could generate more income from the forestry sector. In a written summary of the meeting, the Bupati accused the central government of exploiting the district and halfheartedly carrying out decentralisation. Specifically, he criticised the central government for failing to redistribute income taken out of the district; failing to ensure that the Forest Village Community Development (PMDH or Pembinaan Masyarakat Desa Hutan) programme would benefit local communities; and failing to issue Community Forest Use Right (HPHKm or Hak Pengusahaan Hutan Kemasyarakatan) licenses (Bupati Kotawaringin Timur 2000) ${ }^{8}$.

In light of the central government's failings, the Bupati argued that Laws 22 and 25 had given the provincial and district governments opportunities to assert control over their own natural resource base and to raise their respective incomes by exploiting the district's natural resources. The Bupati consequently decided that Kotawaringin Timur should act on its own initiative and carry out the following activities:

- Issue new district regulations, such as Perda 14 , that aim to obtain more revenue from the forestry sector.

- Form district government-owned companies (Badan Usaha Milik Daerah, or BUMD) to ensure that private companies are not the only ones to benefit from the forestry sector.

- Take over the operations and management of the Forest Village Community Development programme (PMDH). This programme was to be financed through the regional budget (APBD or Anggaran Pendapatan dan Belanja Daerah) with funds originating from timber taxes such as $\mathrm{PMDH}$ payments or through Cooperative and Small Industry Development Funds (Dana Pembinaan Usaha Kecil dan Koperasi).

- Issue forest-use licenses for local communities. The Bupati decided this in spite of the fact that the Ministry of Forestry and Estate Crops issued a letter on 18 April 2000 (138/IV-PS/2000) stating that they would temporarily stop the issuance of these licenses. The Bupati stated that he did not agree with this decision and that the district government would issue a district regulation to enable the Bupati of Kotawaringin Timur to issue these licenses.

- Insist that all timber and plantation companies operating within Kotawaringin Timur establish an office in Sampit. This was to ensure that the district government can easily communicate and negotiate with these companies (Bupati Kotawaringin Timur 2000).

\subsection{SEIZING REVENUE FROM THE PROVINCIAL AND NATIONAL GOVERNMENTS}

In addition to setting forth the above initiatives, the Bupati of Kotawaringin Timur moved to secure additional revenues from the central and provincial governments. For instance, between March 2000 and September 2000, the Bupati had demanded that:

1. Eighty percent of the funds generated from the tax revenues of eleven $\mathrm{HPHs}^{9}$ located within Kotawaringin Timur be returned to the local government. This was said to amount to 80 percent of $\mathrm{Rp} 17$ billion (US\$1.7 million), or Rp 14 billion (US\$1.4 million).

2. Revenue generated from Inhutani III operations in the region be returned to the Kotawaringin Timur government. This was said to amount to 21 percent of $\mathrm{Rp} 1.8$ billion (US\$180,000), or $\mathrm{Rp} 380$ million (US\$38,000).

3. Eighty percent of the revenue generated from the mining sector be returned to the Kotawaringin Timur government ${ }^{10}$. This was said to amount to 80 percent of US\$ $1,055,673$, or just under US\$850,000. 
Not surprisingly, the central and provincial governments did not immediately give in to the Bupati's demands. For instance, when the Bupati requested that revenue generated from $11 \mathrm{HPHs}$ in Kotawaringin Timur be returned to the local government, the Ministry of Finance responded in a letter stating that the Director General of the Finance Department is still following Regulation No. 67/1998 whereby district governments should be allocated 70 percent and the central government allocated 30 percent of the total taxes derived from HPHs. This differs from Law 25, which states that regional governments should receive 80 percent and the central Government 20 percent. The Bupati agreed to this for year 2000 , but made it clear that he would expect to receive 80 percent of the revenue generated from HPHs in the area rather than 70 percent in 2001 (personal communication with the Bupati of Kotawaringin Timur, June 2000).

Similarly, in response to the Bupati's demands for revenue from Inhutani III activities, the governor of Central Kalimantan actually agreed to distribute the funds throughout the districts. How these funds were to be distributed was still being debated in July 2000, but it was to be dependent upon how active Inhutani III was in the districts. According to the Kotawaringin Timur government, around 21 percent of Inhutani III operations fall within the district, which is therefore entitled to 21 percent of the revenue (personal communication with the Provincial Income Office, June 2000). However, the provincial government wished to retain some of these funds and was debating with the Bupati of Kotawaringin Timur as to whether or not the provincial government would retain 50 percent or 40 percent of the funds designated for Kotawaringin Timur. The Bupati of Kotawaringin Timur was obviously arguing for the higher amount, but no decision had been made when fieldwork was completed (personal communication with the Head of Kanwil Pendapatan Daerah, Palangkaraya, June 2000).

\subsection{DISCUSSION}

It is clear that the new decentralisation laws have allowed the Kotawaringin Timur government to wrest control over the district's natural resources, particularly forest resources, in order to increase local revenue. For the year 2000, it was estimated that the Kotawaringin Timur government would generate approximately Rp 62 billion or roughly US\$6.2 million in revenue (Table 8). This represented a 15 -fold increase in local revenue generated in the region for the period 1995-1999, which averaged Rp 3.9 billion (US\$390,000). Over half of the estimated revenue (Rp 35 billion or US\$3.5 million) was obtained from illegal logging, while the remainder came from taxes returned to the district from the central and provincial governments. These taxes were extracted from large-scale logging and mining activities in the district. Increased reliance on the district's forest resources for income is undoubtedly placing further pressure on these resources and increasing rates of deforestation in the area.

Table 8. Estimated Revenue Generated within Kotawaringin Timur, 2000

\begin{tabular}{|c|c|c|}
\hline Revenue Generating Activity & $\begin{array}{c}\text { Percentage of } \\
\text { Total Revenue ('000) }\end{array}$ & $\begin{array}{c}\text { Total Revenue for } \\
\text { Kotawaringin Timur ('000) }\end{array}$ \\
\hline Illegal logging (April-June 2000) & & Rp $11,870,002$ \\
\hline Illegal logging (July-December 2000)a & & $\operatorname{Rp} 23,742,004$ \\
\hline Revenue from HPHs & $70 \%$ of $\operatorname{Rp} 17,686,618=$ & Rp $12,380,633$ \\
\hline Revenue from Inhutani III & $21 \%$ of $\operatorname{Rp~} 1,817,094=$ & Rp 381,590 \\
\hline Revenue from the mining sector & $80 \%$ of US $\$ 1,056=U S \$ 845=$ & $\operatorname{Rp} 8,450,000$ \\
\hline Expected revenue for 2000 before autonomy & & $\operatorname{Rp} 4,952,295$ \\
\hline Total & & $\mathrm{Rp} 61,776,524$ \\
\hline
\end{tabular}

Note: a. This is an estimate generated by dividing the total revenue obtained during the three months of April-June by three and then multiplying by six, which represents the six months from July to December 2000. 
Moreover, as production forests become depleted, pressure is growing on protected forest areas such as Tanjung Puting and Bukit Raya National Parks. These two parks are of global importance as they contain a great deal of biodiversity, including endangered species such as the orangutan. This increased pressure on these two national parks is discussed in further detail below. 


\section{DECENTRALISATION AND PROTECTED AREA MANAGEMENT IN KOTAWARINGIN TIMUR DISTRICT}

Two national parks fall within Kotawaringin Timur-Tanjung Puting National Park and Bukit Raya National Park; however, both of these parks are managed by offices in other districts as they both cross provincial administrative borders. Tanjung Puting National Park is managed by the Natural Resource Conservation Office (Balai Konservasi Sumber Daya Alam, or BKSDA) in Kotawaringin Barat district and Bukit Raya is managed by the Natural Resource Conservation Office in West Kalimantan province.

Located in the south of Kotawaringin Timur, Tanjung Puting National Park occupies an alluvial peninsula jutting out in the Java Sea ${ }^{11}$. Covering an area of 415,000 hectares, Tanjung Puting contains a variety of different ecosystems, including tropical heath forest, peat swamp forest and mangrove forest. Even though much of the park is permanently waterlogged, it contains a number of commercial timber species including meranti (Shorea spp.) and ramin (Gonystylus spp.). A vast array of wildlife can also be found in the park, including over 200 bird species, 17 reptile species and 29 mammal species, many of which are endangered, including the estuarine crocodile, clouded leopard, Malayan sunbear and Storm's stork. Nine of the 13 primate species of Borneo are found in the park, such as the proboscis monkey, the gibbon, the silvery leafeating monkey, and Tanjung Puting's most famous inhabitant- the orangutan (Rijksen and Meijaard 1999).

The present area of the park $(415,040 \mathrm{ha})$ was reached in 1996 after expansion from the original area of 355,000 hectares. There are two small villages (Teluk Pulai and Sel Cabang) in the newer part of the park. The village population is approximately 100 people who live mostly on rubber tapping, rattan production and fishing. The park is more or less surrounded by oil palm plantations (Map 3), and a transmigration site is located on the northern side of the park. There is also a gold-mining site upstream on the river. Demand for land outside the park is thought to be forcing local people into the park in order to access non-timber forest products and timber (personal communication with Birute Galdikas, September 2000).

Bukit Raya National Park is also an area of global importance. The important fauna and flora in the park include three different hornbills: helmeted hornbill (Rhinoplax vigil), rhinoceros hornbill (Bucheros rhinoceros vigil) and black hornbill (Bucheros malayanus), and rafflesia (Rijksen and Meijaard 1999). In accordance with Decree No. 281/Kpts-II/1992, Bukit Raya was declared a National Park in 1992. However, on the most recent paduserasi map, the park is referred to as Hutan Lindung ('Protected Forest'). When district government officials were asked about this ambiguity, noone seemed to know what its true status was. The park includes a wide range of habitats with extremely important flora ranging from undisturbed lowland forests to montane forests, moss forest and ericoid sub-alpine vegetation. Logging companies holding timber concessions located within the park's boundaries were supposedly removed in early 1999. However, a number of HPHs surrounding the park are alleged to be paying local communities to $\log$ the park illegally (personal communication September 2000). 

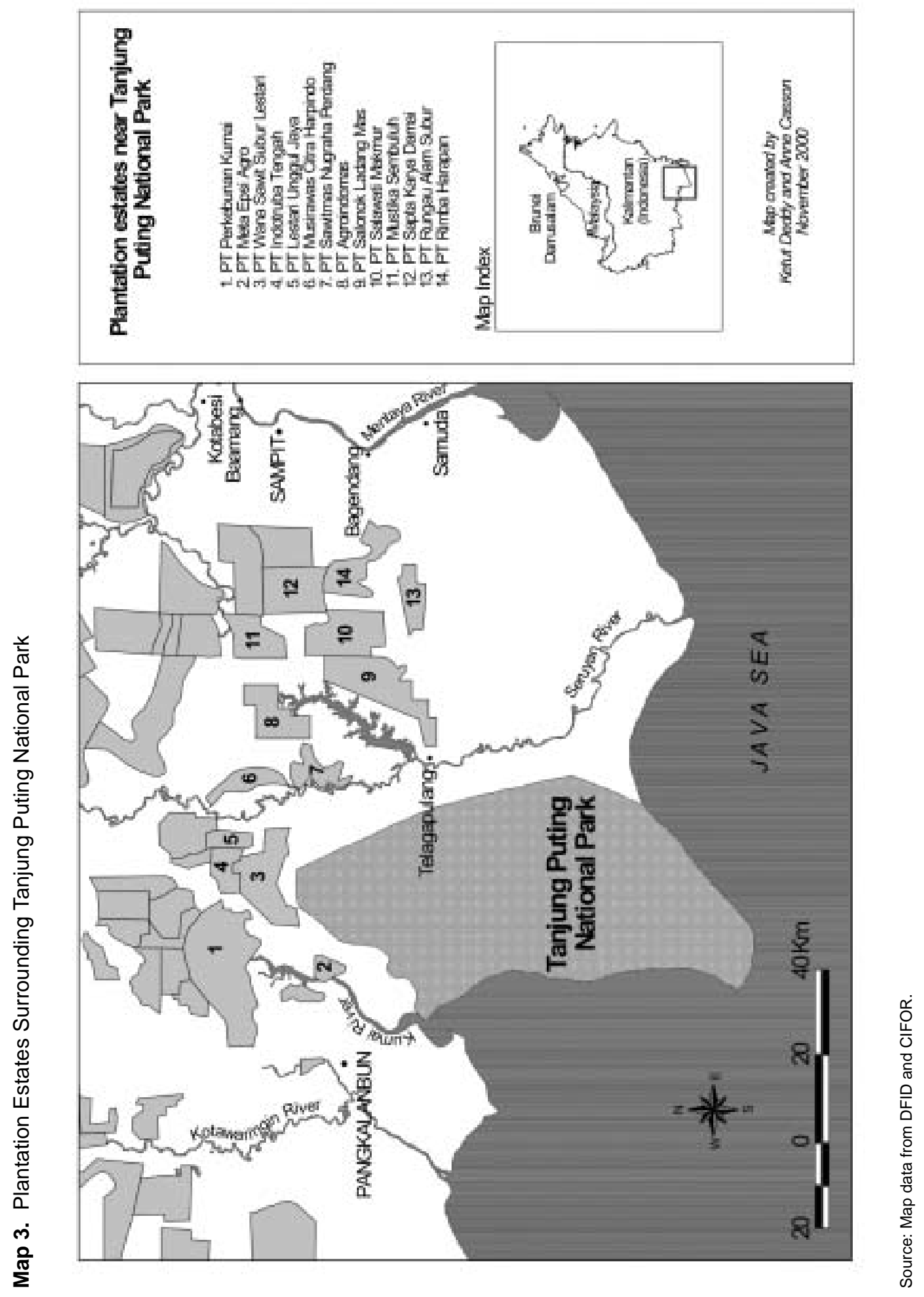


\subsection{ILLEGAL LOGGING IN KOTAWARINGIN TIMUR'S NATIONAL PARKS}

In 2000, most government officials said that they had noticed a rise in illegal logging activities in both parks since the fall of the Soeharto regime in 1998. This has been confirmed by numerous NGO reports that provide evidence of illegal logging, particularly within Tanjung Puting National Park (EIA and Telapak 1999, 2000). Illegal logging is thought to have increased in these areas because the Indonesian army is no longer keeping local people out of these previously forbidden zones. Local people are also moving into these areas because they are some of the last remaining forest areas containing valuable commercial species such as ramin. Also, they felt exploited during the Soeharto era and now feel it is their turn to reap some benefits from their surrounding environment. Although local government officials have made several attempts to eliminate illegal logging in these two parks, their efforts have had little impact. In fact, 96 government employees working for the Natural Resource Conservation Office in Kotawaringin Barat district threatened to resign after their office in Kumai was burnt down by local people in early 2000 (Borneo 2000a). Local people reportedly burnt down the office because the officials had tried to prevent them from logging the park. Some local people have also laid claim to around 60,000 hectares of the parkland. The 60,000 hectares in question was only included in the park in 1996 after it was logged by PT Hezubasah (Banjarmasin Post 2000). The local press is very antagonistic towards environmental activism and regularly questions why the international NGO community is more concerned about the orangutan than people (Borneo 1999a, Borneo 1999b).

Funding from the central government for national park management has also declined since the economic crisis hit Indonesia in 1997. Reduced funding has made it more difficult for local government officials to monitor illegal activities in the park and many, such as the Bupati of Kotawaringin Barat, feel that the park is becoming a district burden (personal communication with the Bupati of Kotawaringin
Barat, June 2000). Moreover, by July 2000, local government officials were unsure as to whether or not responsibilities for the management of the park would change with the advent of decentralisation. Most were adamant that they preferred the central government to be financially responsible for the park and to monitor activities within the parks because they did not feel that they had adequate resources or funds to do so.

Unfortunately, it seems that the concerns raised by the Bupati of Kotawaringin Barat about the management of protected areas such as Tanjung Puting National Park have not been heeded. The Ministry of Forestry and Estate Crops released a regulation that increased local government responsibilities for the management of endangered species such as the orangutan in June 2001 (Indonesian Observer 2001). According to this regulation, governors have been given special rights to issue regulations that both protect endangered species and attempt to reduce their illegal trade and ownership. While the management of the national parks still lies in the hands of the Ministry of Forestry and Estate Crops, local and provincial governments are unlikely to welcome the added responsibility of protecting endangered species when the local populace is more interested in generating income from illegal logging and antagonistic towards any attempts to limit access to forest resources. If the central government continues to neglect the management of these two parks, it is likely that both will lose their ecological value in the very near future. 
As previously mentioned, Kotawaringin Timur is in a process of transition from an economy based on the timber industry to an economy structured around oil palm cultivation. Since the mid-1990s, oil palm area has experienced rapid growth. However, in the current era of economic and political change, oil palm development has slowed by 68 percent, from 29,492 hectares in 1996-97 to 9,568 hectares in 1998-99 (Figure 3). For the year 1999-2000, the government was only expecting 4,036 hectares of oil palm to be planted by private estates in the region. Plans for an 'upland ecological corridor development' that aimed to facilitate oil palm development were put on hold due to a lack of funding.
While the local government is hopeful that regional autonomy will facilitate the development of the oil palm subsector in the near future, rising social conflict-and more recently ethnic conflict-is deterring investment and preventing further area growth. In the Danau Sembuluh area, for example, large-scale private development is planned for the oil palm subsector, but social conflict has been rife. Local government agencies, such as the district estate crop office, have recently become active in the area because they are eager to facilitate the growth of the sector and to ensure that it can generate income for the region. Because valuable forest resources will soon be depleted, economic development seems all the more urgent.

Figure 3. Growth of Private Oil Palm Estates in Central Kalimantan (1996-2000)

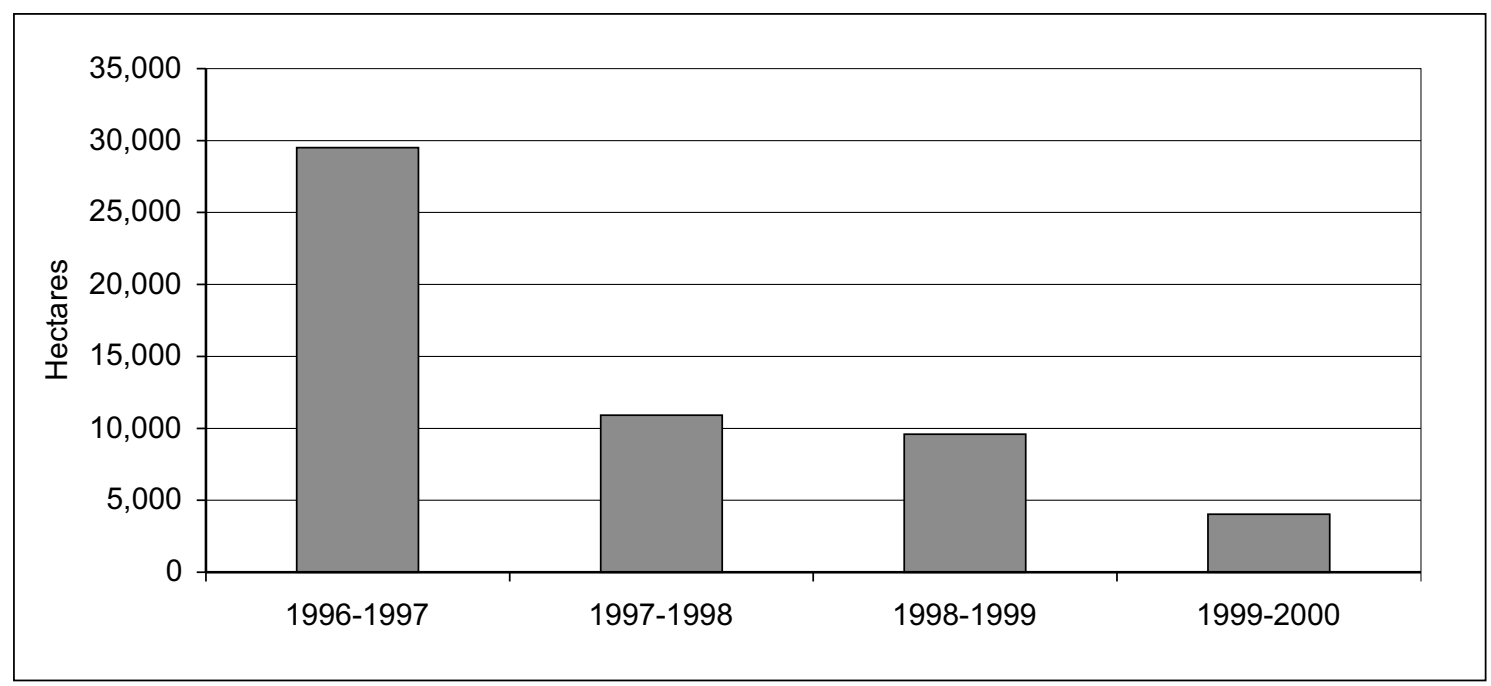

Source: Direktorat Jenderal Perkebunan (2000). 


\subsection{OIL PALM DEVELOPMENT IN THE DANAU SEMBULUH AREA}

Danau Sembuluh subdistrict covers nearly 250,000 hectares and has a total population of around 5,800 (BAPPEDA and BPS 1998). Much of the area was classified as 'Production Forest' in 1967 and subjected to commercial logging during the 1970s. According to the latest paduserasi RTRWP for the area, it has since been reclassified as 'Conversion Forest'. This means that most of the area has been designated for plantation development (Map 4).

The provincial representative of the central government National Land Agency (Badan Pertanahan Negara, or BPN) allocated location permits to 10 companies wishing to establish oil palm plantations in the Danau Sembuluh area. The location permits cover an area of 213,360 hectares. However by mid-2000, the Ministry of Forestry and Estate Crops had only issued forest-release permits to three companies for a total area of 40,570 hectares. The same three companies-PT Musirawas Citra Harpindo, PT Bina Sawit Abadi Pratama I and PT Agro Indomas- had also acquired land -use rights (Hak Guna Usaha, or HGU) from BPN. These three HGUs covered a total area of 39,796 hectares. The area planted by mid-2000 totaled 16,142 hectares. Close to 75 percent of this planted area fell within the concession granted to PT Agro Indomas. Other companies granted concessions in the area delayed planting because they were badly affected by the economic crisis and because the central government was slow to allocate the required permits. They are now also deterred by the social conflict and unrest surrounding PT Agro Indomas, a company with a significant presence in the region. A discussion of PT Agro Indomas highlights some of the social and environmental issues surrounding large-scale oil palm developments.

\subsubsection{PT Agro Indomas}

PT Agro Indomas (PT AI) was initially established as an Indonesian company called PT Bohindomas Permain in 1985; however it became a foreign-owned investment company (Perusahaan Modal Asing, or PMA) in 1996 (Agro Indomas 1998). In the year 2000, Agro Indomas was owned by three Malaysian
companies-Agro Hope Sdn Bhd, Shalimar Developments Sdn Bhd, and Cosville Holding Sdn Bhd-and seven Indonesian entrepreneurs. The Sri Lankan group - Carson Cumberbatchowned and controlled the first two companies, and Agro Hope Sdn Bhd managed the PT Agro Indomas estate in Central Kalimantan (Kurvilla and Mohandas 1997).

In December 1996, the National Land Agency (BPN) granted the company the right to establish oil palm plantations on 12,104 hectares of land and to construct a 60 tonnes/ hour palm oil processing plant in the Danau Sembuluh area. (Agro Indomas 1998). By 1999, most of the concession granted to Agro Indomas had been planted, and the company applied for the right to develop a further 3,760 hectares. The expansion site was approved by the local government in the year 2000, but awaited approval from BPN (Dinas Perkebunan 1999).

Once completed, the entire Agro Indomas project is expected to cost an estimated US $\$ 43$ million (Kurvilla and Mohandas 1997). The majority of these costs have been financed by Rabobank International and the British-based Commonwealth Development Corporation (CDC) (AidEnvironment et al. 2000). Rabobank-one of the largest banks in the Netherlands-provided US\$10.3 million and CDC made an initial investment of US $\$ 14.4$ million in March 1999. As part of the financing agreement, CDC has taken some equity in the project, with a right to sell back the shares to the company at a fixed premium (AidEnvironment et al. 2000). CDC's involvement in the company is of particular interest to international NGOs because the corporation is a British government body that provides long-term loans to businesses in developing countries. It became a private company in December 1999, but the British government (via the Department for International Development-DFID) still holds all its shares. While DFID is not in control of operations or decision-making, CDC has a statutory obligation to operate within DFID's business principles. These principles include clear ethical, environmental, health, safety and social policies (CDC 2000; WALHI Kalteng and Down to Earth 2000).

According to an initial survey of the area conducted by the Agro Indomas company, most 

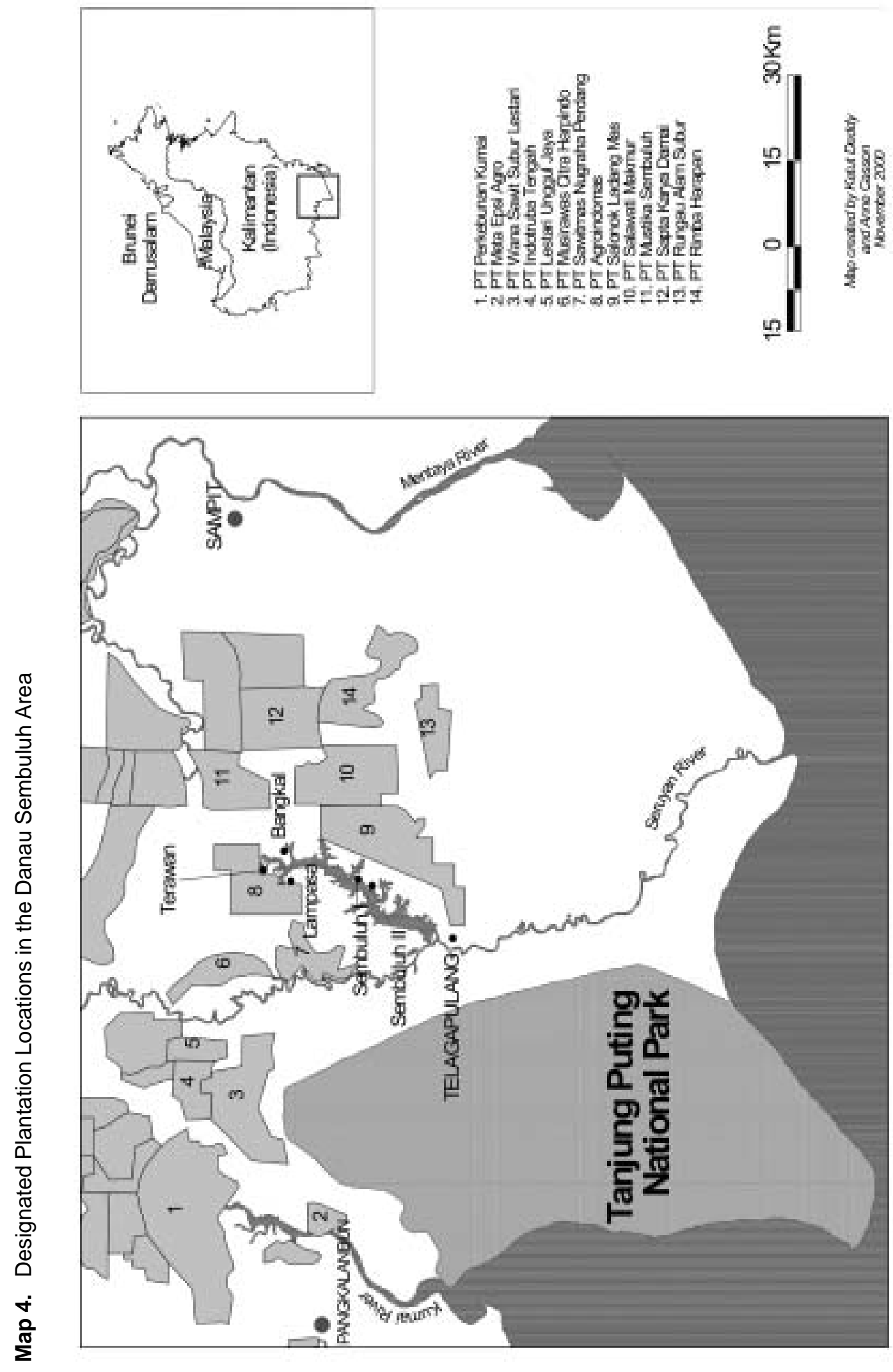

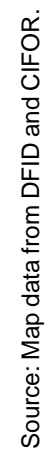


of the land now established by the company was grassland, having been previously logged by Inhutani III. The company was not, therefore, required to obtain a timber clearance permit (IPK), but it did obtain a forest release permit (Pelepasan Kawasan Hutan) and HGU (personal communication with Agro Indomas General Manager, June 2000) ${ }^{12}$. However, a 1998 environmental impact assessment of the company's operations carried out by a Jakartabased consulting agency, PT Shantika Mitra Wiguna, reported that most of the area in the company's concession was said to be secondary forest under the jurisdiction of the Ministry of Forestry (Agro Indomas 1998). Six protected mammal species, including the orangutan, were sighted in the area (Agro Indomas 1998). National and international NGOs have also asserted that the company cleared forest to make way for the plantation (WALHI Kalteng and Down to Earth 2000; AidEnvironment et al. 2000 ). In the year 2000 , the company was found to be in possession of two adult orangutan kept in captivity within the estate grounds.

While 10 villages are officially recognised in the Danau Sembuluh area, the Agro Indomas plantation falls within the administrative boundaries of two villages: Terawan and Sembuluh I. Two other villages: Sembuluh II and Bangkalare also close to the plantation and affected by its operations (Map 4). Bangkal is the only predominantly Dayak village in the area and is approximately one hour away from Sampit by road. The majority of Dayak people in this village are Dayak Tamoan. While most have converted to Christianity, they still practise the Kaharingan religion that places a great deal of emphasis on appeasing the spirits of the dead. The other villages in the area were established in the 1960s and can be accessed by boat across Lake Sembuluh. Most of the inhabitants of these villages are Malay people who came to the area about 30 years ago from South Kalimantan. They refer to themselves as orang Banjar (Banjar people) (personal communications with villagers in the Danau Sembuluh area, June 2000).

While PT Agro Indomas has been successful in achieving its plantation targets in the midst of an economic crisis, it has faced considerable and increasing opposition from some factions of the local community as well as national and international nongovernmental organizations (AidEnvironment et al. 2000; WALHI Kalteng and Down to Earth 2000). These groups argue that the company has taken land from the villagers without consent; has not paid adequate, or in some cases any, compensation; has desecrated graves; and has contributed to an increase in conflict and poverty in the area by replanting forest areas that the local communities were previously reliant upon for their basic needs. The villages of Lampasa and Terawan are probably the most affected by the development, as the oil palm plantation more or less surrounds both of these villages. Before the plantation came to the area, the inhabitants of these villages primarily lived off the nearby forest and lake and did not seem to be involved in agricultural activities. However, the plantation development has meant that villagers now have to go beyond their village boundaries to obtain fuel and other non-timber products required for their daily needs. Access to land surrounding these villages is restricted by the estate.

In an era of economic and political change, conflict between Agro Indomas and communities in the area has increased. While the district officials seek to minimise conflict in the area, many community members believe that their motivations and interests clearly lie with the company. The government is very supportive of companies such as Agro Indomas because they believe that oil palm companies will be an important source of economic investment for Kotawaringin Timur and will be able to generate regional income for the area in the era of regional autonomy.

Like governments in many other districts ${ }^{13}$, the Kotawaringin Timur government is keen to ensure that the Agro Indomas development continues, hoping that other investors will then be attracted to the area. The company in turn uses this argument to gain local government support. For instance, in a local press article the PT Agro Indomas general manager was quoted as saying:

Business prospects in Kotawaringin Timur district are good and will be even better if the local government provides a 
supportive climate for local businesses. The important issue right now for investors is to convince the local government to safeguard businesses. I have seen that the local population does not welcome the presence of plantations. This attitude must be quickly overcome because if it is just left to go on like this it will hamper or delay financial returns for investors and this is not good for the region's image. Quite frankly, I used to have a very positive view of this area, but we have been disappointed by recent events-like the unresolved land compensation cases and the destruction of a bridge on the plantation (Borneo 2000b).

\subsection{OIL PALM PRODUCTION IN AN ERA OF REGIONAL AUTONOMY AND CONSIDERABLE CHANGE}

The recent legislation supporting regional autonomy has undoubtedly facilitated the local government's willingness to support companies such as PT Agro Indomas and other oil palm companies in the district. Since Laws 22 and 25 on regional autonomy were released in 1999, the Bupati of Kotawaringin Timur has embarked on a number of income-generating initiatives, including placing a tax on oil palm production within the region. The local government therefore remains very supportive of companies such as Agro Indomas because it believes that oil palm companies are the future of Kotawaringin Timur and will be able to generate regional income for the district (personal communication with the Bupati of Kotawaringin Timur, June 2000). According to the provincial government, there will be 11 companies with CPO factories operating in Kotawaringin Timur in 2001: PT Agro Indomas, PT Lestari Unggul Jaya, PT Kridatama Lancar, PT Musi Rawas, PT Bina Sawit, PT Kerry Sawit, PT Uni Primacom, PT Hati Prima, PT Bumi Hutan Lestari, PT Surya Barokah and PT London Sumatra. These eleven companies are expected to produce 594 tonnes of crude palm oil (CPO) per day, or as much as 165 tonnes of palm kernel oil (PKO) per day (Borneo 2000c). In 2001, these 11 companies will produce an estimated 178,200 tonnes of CPO and 49,500 tonnes of PKO. Production is expected to gradually increase to 737,100 tonnes of CPO and 175,000 tonnes of PKO in the year 2005 (Borneo 2000c). Given the above, the district government of Kotawaringin Timur is predicting that US $\$ 2.4$ million will be generated from companies whose plantations fall within the district in the year 2001. This is expected to increase to US $\$ 10$ million by the year 2005 (Borneo 2000c). Revenue is to be obtained by taxing companies approximately Rp 5,000 (US\$0.50) per tonne of palm oil produced.

While the district government is optimistic that it can generate revenue from the oil palm subsector, it is unlikely to do so in the near future as most of the companies mentioned above have only just started planting and many have experienced financial problems over the last few years. Moreover, the central government is still maintaining its control over the subsector and the permit allocation process. In the meantime, the local government will continue to generate revenue from illegal logging, large-scale logging and mining. Local government officials are, however, hopeful that regional autonomy will encourage the central government to hand over the allocation of permits to the local government in the near future. At present, the permit process is a long, arduous process controlled by the central government. To obtain a landuse right (HGU), oil palm companies have to obtain a recommendation from the Provincial Land Agency, who passes on the request to the Ministry of Forestry and Estate Crops for a forest-release permit and the National Land Agency for a permit granting 'approval inprincipal' (izin prinsip), a location permit (izin lokasi) and finally a landuse right (HGU). The process may hold up various oil palm developments as it can take anywhere from five to ten years to obtain all the required licenses. The process also tends to be costly, and plantation owners are often required to bribe government officials in order to speed up the process.

Government officials at the provincial and district levels are now arguing for the permit process to be handed over to them. They 
complain that the central government is not serious about regional autonomy because it is refusing to hand over the permit process to the regional governments and instead seems intent on maintaining control over the sector. In an interview, the Governor of Central Kalimantan offered the following description, "the central government continues to hold the head of the snake and will only give us the tail" (pemerintah pusat terus pegang kepala ular dan hanya kasih pemerintah daerah ekornya) (personal communication with the governor of Central Kalimantan). This view has recently been strengthened by the release of Presidential Decree No. 10/2001 concerning the implementation of regional autonomy in the area of land affairs. The decree confirms that previous regulations and decisions on land affairs are still valid, pending the issuance of new regulations based on Law 25. District government officials have criticised the regulation, saying that it is an attempt to maintain the central government's grip on land matters (GTZ 2001).

To gain more control over land affairs, the district and provincial government officials suggested that the Bupati be allowed to issue in-principle approval permits and location permits and that the governor be allowed to issue forest-release permits. They argued that this would enable them to promote further investment by 'mempercepati prosesnya' (speeding up the process). In fact, the Head of the National Land Agency in Palangkaraya thought that the district and provincial governments could issue an HGU within seven working days if the central government released control (personal communication with the head of the district estate crop office, Palangkaraya, March 2000). Little thought had, however, been put into who would carry out the Environmental Impact Assessment (AMDAL) process or ensure that local people were consulted.

There may be some benefits to allowing the regional governments to issue all of the required permits for the development of oil palm estates. For instance, one NGO representative thought that local government officials should have more of an idea about where plantations could be located and should allow local communities and NGOs to participate in the allocation process. They should also be able to better consult with local communities about compensation payments and ensure that their concerns and needs are taken into account. $\mathrm{He}$ went on to say that "regional autonomy will make the local government more responsible to community concerns because the community, and local NGOs, can more easily access them and protest if they do not work in the interests of the local population. The central government, on the other hand, is very far away, and it is impossible for us to influence their decisions" (personal communication with a NGO representative in Palangkaraya, March 2000).

While this may be true, 'speeding up the process' will likely result in an increased rate of forest conversion. There is also a possibility that local government officials will accept bribes in order to push through certain permits and allocate protected forest areas if the 'price is right'. Moreover, few mechanisms exist for local NGOs to protest or question local government decisions. While Paragraph 1 of Law 22 does state that "in the organisation of Regional Autonomy, it is deemed necessary to emphasise more on the principles of democracy, community participation, equitable distribution and justice", no regulations have yet to be released to determine how this is to occur and how community participation in district decisions can be facilitated. Local NGOs in Central Kalimantan, despite their optimism about regional autonomy, have limited capacity and are ill-equipped to open a constructive dialogue with local government ${ }^{14}$. Until the participation of community groups can be ensured, the central government may need to play some role in monitoring the situation and making sure that permits are not allocated in protected forest areas.

The role of provincial governments in the permit process has been unclear. When provincial government officials were interviewed in September 2000 in Palangkaraya, they were extremely confused about the situation and in some cases disturbed by recent developments. They admitted that they and the central government had lost control over what was happening at the district level and were unsure about their role in the near future. The 
Director of the Regional Development Planning Agency (BAPPEDA) even admitted that the Central Kalimantan spatial planning maps could become irrelevant if the Bupati of Kotawaringin Timur started to allocate land-use rights and forest- release permits for oil palm concessions without consulting the provincial or central governments. Unless the Ministry of Forestry gives in to the district governments, the district and central governments will both continue to issue permits, resulting in overlapping permits. While the Bupati had yet to issue any permits by July 2000 he had laid the groundwork for this to occur by drawing up Perda 20 which allowed the Kotawaringin Timur Forest Service (Dinas Kehutanan) and Estate Crop Departments (Dinas Perkebunan) to issue forest-use permits. The regulation also gave these two government offices the authorities to draw up their own spatial planning maps and to determine the boundaries of production, protected and conversion forests.

Officials in the Provincial Estate Crop Office (Kanwil Perkebunan) were also concerned about their jobs as their office was to be disbanded and combined with the Central Kalimantan Forestry Service (Dinas Kehutanan Tingkat I). Any government officials over the age of 50 were to be retired, and many others were to be moved to the district offices. This was causing a great deal of uncertainty and speculation about where various staff members would be transferred to. While there were some calls for provincial governments to be given a greater role in the process, the Bupati of Kotawaringin Timur had become so powerful through his tax-generating initiatives that this was unlikely to occur. The decentralisation laws also bypass the provincial governments and limit their authority and control over decisions at the district level. 


\section{CONCLUSION}

When fieldwork was undertaken for this study in 2000, it appeared that the new decentralisation laws were allowing the Kotawaringin Timur government to seise control over the district's natural resource base and to increase local revenue from the natural resources sector alone. It is estimated that the Kotawaringin Timur government would generate approximately $\mathrm{Rp}$ 62 billion, or roughly US\$6.2 million, in revenue from natural resources alone in 2000. While most of this revenue came from illegal logging, legal logging and mining revenues, the district government was hopeful that the oil palm sector would generate district income in the near future. The local government was keen to develop the oil palm subsector because the district's timber resources were already close to being depleted.

In light of the financial advantages regional autonomy has bestowed upon the Kotawaringin Timur local government, it is going to be very difficult to stop the Bupati or local government from taking more control over their local finances and determining how their natural resources will be exploited. The district government is quite clearly tired of being exploited by outsiders and the central government. It now wants to control its own finances and resources and has already taken a number of steps to ensure that this occurs. For instance, the Kotawaringin Timur government has ratified a district regulation that enables the district government to obtain revenues from 'illegal' logging activities; issued a regulation that grants district forestry and plantation offices more authorities; taken over the operations and management of the community forestry program; insisted that the central government hand over revenue taken from Inhutani and private logging operations in the district; and demanded that the central government return 80 percent of revenue obtained from mining activities in the region. All this, despite the fact that the decentralisation laws were only due to come into effect in January 2001.

Although it is difficult to deny the district government opportunities to generate more income from natural resources, a number of the initiatives developed to generate this income are undoubtedly having a detrimental effect on the district's environment. District government decisions are seemingly driven by short-term economic goals and natural resource exploitation. Perda 14, for instance, is definitely increasing the rate of deforestation in the region. Once the district's timber has been exploited, the district government will have little choice but to turn to the oil palm subsector as the district's main income generator. An increase in oil palm development will inevitably lead to an increase in land conflict and will marginalise forest-dependent communities. Local governments need immediate help. They need to develop strategies for generating sustainable revenue, and they need to better understand the real worth of the district's natural resource base. The district government will also need assistance with spatial planning and will need information about some of the long-term impacts of planned developments such as the 'upland ecological corridor'. Finally, help is also necessary to determine how much timber can be harvested per year in order to ensure that all of the district's 
valuable timber supplies are not exhausted. In other words, long-term planning is required in the area, and local government officials need to be made more aware of the social and environmental consequences of both extensive logging (legal and illegal) and future plans to facilitate large-scale oil palm development in the district.

\section{POSTSCRIPT}

In February 2001, violent riots broke out in the capital of Kotawaringin Timur-Sampit. The conflict is alleged to have erupted after a mob attacked a migrant settlement area in the early hours of the morning, leaving eight people dead and several in critical condition (Jakarta Post 2001a). Shortly after this incident, a number of Madurese migrants are alleged to have retaliated, sparking off widespread ethnic violence in the district. Official reports now claim that up to 250 lives have been lost to the violence. Some are claiming that the death toll is likely to reach 400 (Jakarta Post 2001d). The unrest has caused thousands of people to flee the area. Most of those fleeing are thought to be migrant settlers and civil servants from local government offices (Jakarta Post 2001b).

The riots are thought to have been masterminded by two district government officials who are believed to have paid six men a total of Rp 20 million (US\$2,000) to provoke the disturbances (Jakarta Post 2001b). Both of these officials are believed to have masterminded the riots because they had lost their jobs as a consequence of the regional autonomy programme. As mentioned above, because several provincial offices were disbanded, provincial government officials were to be transferred to the districts. This has led to the demotion, or removal, of several district officials.

The recent outbreak of violence will inevitably have an impact on the Kotawaringin Timur economy and mayundermine confidence in the Bupati and the Kotawaringin Timur government. It may also weaken the ability of the local government to function if it is true that a number of government officials were forced to leave the area. Violence in the district will inevitably deter investors from the sector until the district government can maintain security and ensure investors that future violence will not occur in the region. This point has been emphasised by the House of Representatives speaker, Akbar Tanjung, who recently warned that "if the Sampit case is not resolved, it will have a negative impact on prospective foreign investment who wish to conduct business in Kalimantan. Footage of people getting their heads chopped off will scare people away" (Jakarta Post 2001c). 


\section{ENDNOTES}

${ }^{1}$ Any reproduction should mention the title of the report and credit CIFOR as the publisher. The correct citation for this paper is: Casson, A. 2001. Decentralisation of policies affecting forests and estate crops in Kotawaringin Timur District, Central Kalimantan, Case Study 5. CIFOR, Bogor Indonesia.

${ }^{2}$ Between 1969 and 1997, a total of 82,487 people were moved from Java and Madura to Central Kalimantan (JICA and BAPPENAS 1999), Vol 4.

${ }^{3}$ The exhange rate used throughout this paper is $\mathrm{Rp} 10,000$ to the US dollar.

${ }^{4}$ In order to make more concrete land-use plans, the provincial government of Central Kalimantan has been formulating a modified land-use plan reconciling the Forest Land-Use Plan by Consensus (Tata Guna Hutan Kesepakatan, TGHK) drawn up in 1982 with the 1995 Provincial LandUse Plan (Rencana Tata Ruang Wilayah Propinsi, RTRWP). The 'reconciled landuse plan', or paduserasi is supposed to be a modified RTRWP agreed upon by both central government ministries and governors.

${ }^{5}$ The Bupati's income-generation performance is often compared to the poor performance of the former Bupati who was only able to generate US $\$ 500,000$ in one year.

${ }^{6}$ The Perda must also address certain criteria. These 'good tax' criteria assert that (1) tax objects must be located in the particular local governments and possess relatively low mobility across local government boundaries; (2) the tax does not contradict the public interest; (3) the tax does not constitute a national or provincial $\operatorname{tax}$; (4) the tax has sufficient revenue potential; (5) implementation of the tax will not negatively impact the local economy; (6) development of the tax takes into consideration issues of fairness to and capacity of local residents; and (7) the tax protects environmental conservation. While Perda 14 clearly does not protect environmental conservation, the district government is more likely to focus on the fact that the central government has legitimised its ability to tax 'illegal' carriers and reap the benefits.

${ }^{7}$ The Provincial Forest and Estate Crop Offices (Kanwil Kehutanan and Kanwil Perkebunan) were previously responsible to the central government and had the authority to issue legislation about forest management and control. Before regional autonomy, the district forest service (Dinas Kehutanan Tingkat II) and Estate Crop Department (Dinas Perkebunan Tingkat II) were responsible to their respective Bupati's and the governor. Both of these offices had limited authorities and their primary task was to monitor forest activities and collect statistics on production.

${ }^{8}$ The Bupati claims that since the Ministry of Forestry and Plantation Estates issued Regulation No. 677/Kpts-II/1999 about community forestry, it has only issued three HPHKm licenses to three cooperatives: Koperasi Rimba Dayak Membangun, Koperasi Berkat Usaha Mandiri and Koperasi Sakaha Jaya.

${ }^{9}$ The central government originally said that they would only return revenue generated from four HPHs in the region. The Bupati of Kotawaringin Timur then wrote a letter pointing out that there 
were $11 \mathrm{HPH}$ companies in the region that had contributed funds to the central government over the last year.

${ }^{10}$ In August 2000, the Ministry of Finance returned \$US1,055,673-income generated from the mining sector in the province- to the Central Kalimantan government.

${ }^{11}$ Tanjung Puting National Park is a conservation area of global importance. It is recognized as a World Biosphere Reserve by the United Nations and forms the largest protected area of swamp forest in the South-East Asia region. It was awarded National Park status in 1986 after being classified as a wildlife reserve in 1939. The area was brought to international attention by the activities of Birute Galdikas and her then husband Rod Brindamour, when they established an orangutan rehabilitation project along a tributary of the Sekonyer River
(1972-91). Galdikas was one of three researchers recruited by Louis Leakey to study the link between the apes and humans (Rijksen and Meijaard 1999).

${ }^{12}$ The General Manager had come to Central Kalimantan about six years earlier to establish the nursery. At this time, he claims to have lived in the two villages closest to the plantationTerawan and Lampasa-and surveyed how many houses were in the villages as well as the trees belonging to those villages.

${ }^{13}$ For instance see discussion on PT London Sumatra in case study No. 4 on Kutai Barat District, East Kalimantan.

${ }^{14}$ This becomes particularly obvious when the capacity of NGOs in Central Kalimantan is compared to the capacity of their counterparts in Samarinda, East Kalimantan (see case study No. 4 on Kutai Barat District, East Kalimantan.) 


\section{REFERENCES}

Agro Indomas 1998. PT Agro Indomas, Analysis Dampak Linkungan (ANDAL): Perkebunan dan Pabrik Kelapa Sawit PT Agro Indomas di Kecamatan Danau Sembuluh, Kabupaten Kotawaringin Timur, Propinsi Kalimantan Tengah. PT Agro Indomas, Sampit, Central Kalimantan.

AidEnvironment, Telapak and Contrast Advies 2000. Funding Forest Destruction: The involvement of Dutch banks in the financing of oil palm plantations in Indonesia. Report for Greenpeace Netherlands, Amsterdam, The Netherlands.

Anwar, HMW. 2000. Visi dan Misi Kotim: Pembangungan Manusia Berkelanjutan, dalam rangka penyampaian visi dan misi oleh para bakal calon Regent Kab. Kotim Periode tahun 2000-2005 di depan rapat paripurna DPRD. District Kotawaringin Timur, Samarinda.

Ascher, W. 1995. Communities and Sustainable Forestry in Developing Countries. San Francisco: ICS Press.

Banjarmasin Post 2000. 96 Karyawan TNTP Mundur. February 11.

BAPPEDA and BPS 1998. Peluang dan potensi investasi District Kotawaringin Timur, Bupi Babaring Hurung. Bappeda Kotawaringin Timur and Badan Pusat Statistik Kotawaringin Timur, Sampit, Central Kalimantan.

Barr, C. 2001a. Banking on Sustainability: Structural Adjustment and Forestry Reform in Post-Soeharto Indonesia, Washington, DC: Center for International Forestry Research (CIFOR) and WWF Macroeconomics Program Office.
Barr, C. 2001b. Will HPH Reform Lead to Sustainable Forest Management?: Questioning the Assumptions of the 'Sustainable Logging' Paradigm, in Indonesia. Forthcoming in Colfer, C.J.P. and Resosudarmo, I.A.P. (eds.), Which Way Forward? Forests, Policy and People in Indonesia. Washington D.C.: Resources for the Future.

Borneo 1999a. Kontroversi Prof Birute MF Galdikas, Borneo. September 11:15.

Borneo 1999b. Orang Asing Lebih Peduli Kelestarian Hutan Kalimantan. December 5.

Borneo 2000a. BPKA TNTP dirusak massa sejumlah pejabat mundur. February 16.

Borneo. 2000b. Perintis Kebun Sawit Kotim yang Lahir dari Semangat ASEAN. No.12/ Tahun, Awal Maret, Sampit.

Borneo 2000c. Kampanye Internasional Ancam Investasi Perkebunan Kelapa Sawit Kalteng Waspadai Tangan Kotor Asing dan Petualang yang Atasnamakan Rakyat Tabloid Borneo. No. 24 Tahun II Medio September.

Bupati Kotawaringan Timur. 2000. Bahan Paparan: Bupati Kabupaten Kotawaringin Timur: Dalam rangka pertemuan dengan penusaha kehutanan. Pemda Kotawaringin Timur, Sampit.

BPS and Bappeda 1998. Kalimantan Tengah dalam Angka, 1998. Bappeda District Kotim dan Badan Pusat Statistik District Kotim, Sampit, Central Kalimantan. 
Brandon, K.E. and Wells, M. 1992. Planning for People and Parks: Design Dilemmas. World Development 20 (4):557-70.

Brookfield, H., Potter, L. and Byron, Y. 1995. In Place of the Forest: Environmental and socio-economic transformation in Borneo and the Eastern Malay Peninsula. United Nations University Press, Tokyo.

CDC. 2001. CDC Development Partners. CDC Webpage, http://www.cdcgroup.com/.

Carney, D. 1995. Management and Supply in Agriculture and Natural Resources: Is Decentralisation the Answer? Overseas Development Institute Natural Resources Perspectives No. 4. London: Overseas Development Institute.

Conyers, D. 1981. Decentralization for Regional Development: A Comparative Study of Tanzania, Zambia, and Papua New Guinea. Public Administration and Development 1 (2):107-20.

Departemen Kehutanan dan Perkebunan 1999. Palangkaraya, Statistik Kehutanan dan Perkebunan Propinsi Kalimantan Tengah. Kantor Wilayah Propinsi Kalimantan Tengah, Palangkaraya.

Departemen Kehutanan dan Perkebunan 1996. Statistik Perkebunan Indonesia, 19951997, Kelapa Sawit. Departemen Pertanian Direktorat Jenderal Perkebunan, Jakarta.

Departemen Kehutanan dan Perkebunan 1997. Statistik Perkebunan Indonesia, 19961998, Kelapa Sawit. Departemen Pertanian Direktorat Jenderal Perkebunan, Jakarta.

Departemen Kehutanan dan Perkebunan 1998. Statistik Perkebunan Indonesia, 19971999, Kelapa Sawit. Departemen Kehutanan dan Perkebunan, Jakarta.

Departemen Kehutanan dan Perkebunan 2000. Statistik Perkebunan Indonesia, 19982000, Kelapa Sawit. Departemen Kehutanan dan Perkebunan, Jakarta, Indonesia.

Dinas Kehutanan 1999. Statistik Kotawaringan Timur. Dinas Kehutanan Kotawaringan Timur, Sampit, Central Kalimantan.

Dinas Perkebunan 1999. Statistik Perkebunan

Tahun 1999. Pemerintah Propinsi Kalimantan Tengah, Dinas Perkebunan, Palangkaraya, Central Kalimantan.
Environmental Investigation Agency (EIA) and Telapak 1999. The Final Cut: Illegal logging in Indonesia's orang-utan parks. Environmental Investigation Agency, London, UK and Telapak, Bogor, Indonesia, Emmerson Press, UK.

Environmental Investigation Agency (EIA) and Telapak 2000. Illegal Logging in Tanjung Puting National Park: An update on the Final Cut Report. Environmental Investigation Agency and Telapak, Emmerson Press, UK.

GTZ 2001. Decentralisation News. Issue No. 5, February.

Holmes, D. 2000. Deforestation in Indonesia: A review of the situation in 1999. Draft report for the World Bank, Jakarta.

Indonesian Observer 2001. Indon governors given authority to protect endangered species. June 6.

Indonesia-UK Tropical Forest Management Programme (ITFMP) 1999. Illegal Logging in Indonesia. Report No. PFM/ EC/99/03.

Jakarta Post 2001a. Eight dead as riot hits Sampit, Central Kalimantan. February 19.

Jakarta Post 2001b. Masterminds of ethnic riot sought, Sampit still tense. February 20.

Jakarta Post 2001c. Tension remains in violence hit Sampit. February 24.

Jakarta Post 2001d. Sampit revisited. February 25.

JICA and BAPPENAS 1999a. The Development Study on Comprehensive Regional Development Plan for the Western Part of Kalimantan, SCRDP-KaltengBar. Final Report, Vol 3. Japan International Cooperation Agency and the National Development Planning Agency, Jakarta.

JICA and BAPPENAS 1999b. The Development Study on Comprehensive Regional Development Plan for The Western Part of Kalimantan SCRDPKalTengBar. Final Report, Vol 4. Japan International Cooperation Agency and the National Development Planning Agency, Jakarta.

JICA and BAPPENAS 1998. The Development Study on Comprehensive Regional Development Plan for the Western Part of 
Kalimantan. Draft final report, Executive Summary, JICA, Jakarta.

Kaimowitz, D., Christian, V., Pablo, P. and Raul, L. 1998. Municipal Governments and Forest Management in Lowland Bolivia. Journal of Environment and Development. Vol. 7, No. 1, March: 45-59.

Kalteng Pos 2000. Pemkab sosialisasikan peraturan daerah kayu. Senin, 3 Juli:4.

King V. 1993. The Peoples of Borneo. Blackwell, Oxford.

Kurvilla, K. and Mohandas, N. 1997. Challenges in Large-scale Oil Palm Planting in Central Kalimantan. A paper presented at the International Planters Conference, 21-22 May 1997, Malaysia.

Mubyarto and Baswir, R. 1989. Central Kalimantan: The Dayak Heartland. In: Hill, H., Unity and Diversity: Regional economic development in Indonesia since 1970. Oxford University Press, Oxford.

Ostrom, E. 1990. Governing the Commons: The Evolution of Institutions for Collective Action. Cambridge: Cambridge University Press.

Potter, L. 1990. Forest Classification, Policy and Land-Use Planning in Kalimantan. Borneo Review, 1(1): 91-128.

Rijksen, H.D. and Meijaard, E.1999. Our Vanishing Relative: The Status of Wild Orang-utans at the Close of the Twentieth Century. Kluwer Academic Publishers, Dordrecht, The Netherlands.

Rivera, R. 1996. Decentralización y gestión local en América Latina. San Jose: FLACSO.

Rondinelli, D., Nellis, J.R. and Cheema, G.S. 1983. Decentralization in Developing Countries: A Review of Recent Experience.
Staff Working Papers No. 581. Washington D.C.: World Bank.

Scotland, N., Frazer, A. and Jewell, N. 1999. Roundwood Supply and Demand in the Forest Sector in Indonesia. Indonesia-UK Tropical Forest Management Programme, Report No. PFM/EC/99/08 (November 23rd draft). Jakarta, Indonesia.

Sellato, B. 2001. Culture, History, Politics and the Emergence of Provincial Identities in Kalimantan. In: Charras, M., ed., Beyond the state: Essays on spatial structuration in insular Southeast Asia. LASEMA/CNRS, Paris. In Press.

Sunderlin, W.D., Resosudarmo, I.A.P., Rianto, E., and Angelsen, A. 2000. The Effect of Indonesia's Economic Crisis on Small Farmers and Natural Forest Cover in the Outer Islands. CIFOR Occasional Paper No. 28(E). Bogor, Indonesia: Center for International Forestry Research.

Toha, M. 2000. Estimated Deforestation Rate for Indonesia. Unpublished presentation prepared for the CGI Seminar on Indonesian Forestry. Jakarta. January 26.

Utting, P. 1993. Trees, People, and Power: Social Dimensions of Deforestation and Forest Protection in Central America. London: Earthscan.

WALHI Kalteng and Down to Earth 2000. The Dispute between the local community and PT Agro Indomas Oil Palm Plantation Central Kalimantan, Indonesia. September 2000, WALHI Kalteng and Down to Earth, London/Palangkaraya.

World Bank 2001. Indonesia: Environment and Natural Resource Management in a Time of Transition. Washington, DC: World Bank. 
Appendix A. HPH in Kotawaringin Timur District, 2000

\begin{tabular}{|c|c|c|c|}
\hline Company & Area $(1,000 \mathrm{ha})$ & $\begin{array}{c}\text { Date Concession } \\
\text { Obtained }\end{array}$ & $\begin{array}{c}\text { Active (A) or } \\
\text { Not Active (NA) }\end{array}$ \\
\hline \multicolumn{4}{|l|}{ CDK Mentaya } \\
\hline PT Perkasa Wana & 85 & 1981 & $A$ \\
\hline PT Parakantja J Raya & 80 & 1973 & $A$ \\
\hline PT Sarpatim & 170 & 1973 & $A$ \\
\hline PT Bina Samaktha II & 40 & 1979 & $A$ \\
\hline PT Balambit & 90 & 1976 & $A$ \\
\hline PT Mentaya Kalang & 40 & 1974 & NA \\
\hline PT Bina Samaktha II A & 50 & 1979 & $A$ \\
\hline PT Inhutani III & 715 & 1970 & $A$ \\
\hline PT Meranti Mustika & 60 & 1979 & $A$ \\
\hline PT Yusmin Trading & 95 & 1974 & $A$ \\
\hline PT Berkat Chaya & 110 & 1973 & $A$ \\
\hline PT Kayu Tribuana Rama & 95 & 1978 & $A$ \\
\hline \multicolumn{4}{|l|}{ CDK Katingan Hilir } \\
\hline PT Brajatama/Yidi Jaya & 60 & 1977 & $A$ \\
\hline PT Simanggang Hayu & 133 & 1973 & \\
\hline PT Kalimantan Hayu & 67.5 & 1972 & PT Inhutani III \\
\hline PT Kalang Baru & 30 & 1976 & PT Inhutani III \\
\hline PT Brajatama/Tj Raya & 60 & 1976 & PT Inhutani III \\
\hline PT Good Timber & 60 & 1979 & A \\
\hline PT Sumber Aman Raya & 40 & 1973 & PT Inhutani III \\
\hline PT Batarung & 65 & 1971 & $\begin{array}{l}\text { PT Inhutani III } \\
\text { PT Inhutani III }\end{array}$ \\
\hline CDK Katingan Hulu & & & A \\
\hline PT Katunen & 60 & 1976 & PT Inhutani III \\
\hline PT Kayon TC I & 40 & 1973 & PT Inhutani III \\
\hline PT Rathitara & 182 & 1974 & PT Inhutani III \\
\hline PT Katingan TC & 110 & 1974 & NA \\
\hline PT Wira Sarayatama & 50 & 1974 & NA \\
\hline PT Hutal Mulya & 80 & 1973 & $A$ \\
\hline PT Kayu Waja & 72 & 1980 & $A$ \\
\hline PT Handayani and Co & 100 & 1976 & $A$ \\
\hline PT Dwima Jaya Utama & 159 & 1977 & $A$ \\
\hline PT Carus Indonesia & 49 & 1980 & $A$ \\
\hline \multirow[t]{2}{*}{ PT Mantikei } & 40 & 1978 & $A$ \\
\hline & & & $A$ \\
\hline CDK Seruyan & & & $A$ \\
\hline PT Sari Bumi Kusuma & 280 & 1978 & $A$ \\
\hline PT Erna Djuliawati & 185 & 1987 & $A$ \\
\hline PT Bina Samaktha & 170 & 1987 & $A$ \\
\hline PT Mountrado Jaya & 75 & 1972 & $A$ \\
\hline PT Bina Dwima Jaya & 85 & 1978 & A \\
\hline PT Kayu Klaban Timber & 75 & 1974 & PT Inhutani III \\
\hline PT Mulung Basidi & 98 & 1980 & A \\
\hline PT Gajah Seno Sakti & 53 & & $A$ \\
\hline PT Lam Jaya Utama & 70 & 1979 & $A$ \\
\hline Total & 4178.5 & & \\
\hline
\end{tabular}


Appendix B. Applications for Oil Palm Developments and the Release of Forest Land in Kotawaringin Timur District, 2000

\begin{tabular}{|c|c|c|c|c|c|c|}
\hline Company & Location & Commodity & $\begin{array}{l}\text { Location } \\
\text { Permit }\end{array}$ & $\begin{array}{l}\text { Release } \\
\text { of Forest } \\
\text { Land }(\mathrm{Ha})\end{array}$ & $\begin{array}{l}\text { Release of } \\
\text { Community } \\
\text { Land (Ha) }\end{array}$ & $\begin{array}{l}\text { HGU } \\
(\mathrm{Ha})\end{array}$ \\
\hline 1 PT Samba Sakti Perkasa & Kalingan Tengah & Cocoa & 5,000 & 4,986 & & \\
\hline 2 PT Tunjang Jaya & Kota Besi & Oil palm & 10,000 & & & \\
\hline 3 PT Sapta karya Damai & Baamang & Oil palm & 17,500 & 13,135 & & 11,382 \\
\hline 4 PT Lawang Haring Perkasa & Kota Besi & Oil palm & $\begin{array}{l}17,500 \\
17,500\end{array}$ & & & \\
\hline 5 PT Mustika Sembuluh & $\begin{array}{l}\text { D Sembuluh } \\
\text { Sei Babi }\end{array}$ & Oil palm & 17,500 & 7,500 & & In process \\
\hline 6 PT Sukajadi Sawit Mekar & Kota Besi & Oil palm & 15,000 & 7,000 & & 7,416 \\
\hline $\begin{array}{l}7 \text { PT Keri Sawit Indonesia } \\
\text { Ek PT Salawati }\end{array}$ & $\begin{array}{l}\text { Danau Sembuluh, } \\
\text { Seruyan Hilir }\end{array}$ & Oil palm & $\begin{array}{l}17,500 \\
17,500\end{array}$ & & & In process \\
\hline 8 PT Teguh Sempurna & $\begin{array}{l}\text { Seruyan Hulu, } \\
\text { Seruyan Hilir }\end{array}$ & Oil palm & 25,000 & 16,300 & & 16,601 \\
\hline 9 PT Kridatama Lancar & $\begin{array}{l}\text { Seruyan Hulu, } \\
\text { Seruyan Tengah }\end{array}$ & Oil palm & 25,000 & 15,900 & & 14,779 \\
\hline 10 PT Musi Rawas Citra Harpindo & $\begin{array}{l}\text { Danau Sembuluh, } \\
\text { Hanau }\end{array}$ & Oil palm & 12,500 & 7,790 & & 7,512 \\
\hline 11 PT Trimeru & Mentaya Hulu & Oil palm & $\begin{array}{l}17,500 \\
17,500\end{array}$ & 14,615 & & \\
\hline 12 PT Karunia Lama Mentaya Jaya & $\begin{array}{l}\text { Pulau Walan, } \\
\text { Kuluk Bali, } \\
\text { Wandaing Lawa } \\
\text { Tb Karang }\end{array}$ & Oil palm & 17,500 & 10,380 & & In process \\
\hline 13 PT Bumi Hutani Lestari & Katingan Tengah & Oil palm & $\begin{array}{l}17,500 \\
17,500\end{array}$ & 14,929 & & 14,929 \\
\hline 14 PT Graha Jaya Abadi & $\begin{array}{l}\text { Tanjung Jorong, } \\
\text { Kuala Kuayan }\end{array}$ & Oil palm & 13,643 & 0 & & \\
\hline 15 PT Bina Sawit Abadi Pratama I & $\begin{array}{l}\text { Seruyan Tengah, } \\
\text { Danau Sembuluh }\end{array}$ & Oil palm & 25,000 & 17,780 & & 20,180 \\
\hline 16 PT Karunia Alam Mentaya Utama & $\begin{array}{l}\text { Pulau Malan } \\
\text { Katingan Tengah }\end{array}$ & Oil palm & 17,500 & 10,752 & & \\
\hline 17 PT Gema Wina Kencana & $\begin{array}{l}\text { Tewang katingan, } \\
\text { Sangalang Garing, } \\
\text { Cempaga }\end{array}$ & Oil palm & 17,500 & & & \\
\hline 18 PT Wonodon Cahaya Hijau & $\begin{array}{l}\text { Mentaya Hulu, } \\
\text { Parenggean, } \\
\text { Katingan Tengah }\end{array}$ & Oil palm & 17,500 & & & \\
\hline 19 PT Surya Barokah & Cempaga & Oil palm & 17,500 & 12,187 & & \\
\hline 20 PT Putra Mentaya & Katingan Tengah & Oil palm & 7,000 & & & \\
\hline $\begin{array}{l}21 \text { PT Agro Indomas } \\
\text { Ek PT Bohindomas Permai }\end{array}$ & Danau Sembuluh & Oil palm & $\begin{array}{l}12,000 \\
12,000\end{array}$ & & & 12,104 \\
\hline 22 PT Rotanawa Sejati & Seruyan Tengah & Oil palm & 15,000 & & & \\
\hline $\begin{array}{l}23 \text { PT Bandarin International } \\
\text { Industry }\end{array}$ & $\begin{array}{l}\text { Parenggean, } \\
\text { Mentaya Hulu }\end{array}$ & Oil palm & 17,500 & & & \\
\hline 24 PT Agro Mandiri Perdana & Parenggean & Oil palm & $\begin{array}{l}15,000 \\
15,000\end{array}$ & & & \\
\hline $\begin{array}{l}25 \text { PT Transindo } \\
\text { Ex PT Badra }\end{array}$ & Cembaga & Oil palm & 10,000 & & & \\
\hline
\end{tabular}


Appendix B. Continued

\begin{tabular}{|c|c|c|c|c|c|c|c|}
\hline & Company & Location & Commodity & $\begin{array}{l}\text { Location } \\
\text { Permit }\end{array}$ & $\begin{array}{l}\text { Release } \\
\text { of Forest } \\
\text { Land (Ha) }\end{array}$ & $\begin{array}{l}\text { Release of } \\
\text { Community } \\
\text { Land (Ha) }\end{array}$ & $\begin{array}{l}\text { HGU } \\
(\mathrm{Ha})\end{array}$ \\
\hline 26 & $\begin{array}{l}\text { PT Tunas Agro Subur Kencana } \\
\text { Ex PT Badra Cipta } \\
\text { Ex PT Karya Mandiri }\end{array}$ & Cempaga & Oil palm & $\begin{array}{l}15,000 \\
21,210\end{array}$ & & & \\
\hline 27 & $\begin{array}{l}\text { PT Centra Borneo Agro Persada } \\
\text { Ex PT Surya Raya Amarta }\end{array}$ & Cempaga & Oil palm & $\begin{array}{l}10,600 \\
15,000\end{array}$ & & & \\
\hline 28 & 3 PT Bhadra Cemerlang & Cempaga & Oil palm & 20,000 & & & \\
\hline 29 & PT Lestari Unggul Jaya I & Pembuang Hulu & Oil palm & $\begin{array}{l}30,000 \\
15,920\end{array}$ & 5,400 & 4,890 & \\
\hline 30 & PT Sawit Prima Subur & $\begin{array}{l}\text { Katingan engah, } \\
\text { Sanaman Mantikei }\end{array}$ & ei & 17,500 & & & \\
\hline 31 & PT Windu Nabatindo Lestari & Cempaga & Oil palm & 17,500 & 11,550 & & \\
\hline 32 & PT Bangkit Giat Usaha Mandiri & Pembuang Hulu & Oil palm & 15,000 & 9,221 & & 2,000 \\
\hline 33 & 3 PT Rungau Alam Subur & Danau Sembuluh & Oil palm & $\begin{array}{l}17,500 \\
17,500\end{array}$ & & & \\
\hline 34 & PT Wanasawit Subur Lestari & & Oil palm & 10,000 & 17,598 & & 6,400 \\
\hline 35 & 5 PT Salonok Ladang Mas & Seruyan Hilir & Oil palm & $\begin{array}{l}17,500 \\
17,500\end{array}$ & & & \\
\hline 36 & PT Rimba Harapan Sakti & Seruyan Hilir & Oil palm & 17,500 & & & \\
\hline 37 & PT Aditunggal Wahajaya & Seruyan Tengah & Oil palm & $\begin{array}{l}17,000 \\
17,000\end{array}$ & & & \\
\hline 38 & PT Hamanesia & Kota Besi & Oil palm & 15,000 & & & \\
\hline 39 & $\begin{array}{l}\text { PT Sawitmas Nugra } \\
\text { Ha Perdana }\end{array}$ & Danau Sembuluh & Oil palm & $\begin{array}{l}15,000 \\
17,500\end{array}$ & & & \\
\hline 40 & PT Indrogunas Pratama & Parenggean & Oil palm & 17,500 & & & \\
\hline 41 & PT Indogunas Sakti & Parenggean & Oil palm & 17,000 & & & \\
\hline 42 & PT Karya Makmur Bahagia & Mentaya Hulu & Oil palm & 12,500 & 12,706 & & 2,500 \\
\hline 43 & 3 PT Karya Makmur Bahagia & Mentaya Hulu & Oil palm & 5,000 & & & \\
\hline 44 & PT Karya Agro Palma & Kota Besi & Oil palm & $\begin{array}{l}17,500 \\
17,500\end{array}$ & & & \\
\hline 45 & $\begin{array}{l}5 \text { PT Katingan Indah Utama } \\
\text { Ex PT Duat Duat Kharisma }\end{array}$ & Parenggean & Oil palm & 12,000 & & & \\
\hline 46 & PT Arya Harapan Sejahtera & $\begin{array}{l}\text { Mentaya Hulu, } \\
\text { Marikit and } \\
\text { Katingan Tengah }\end{array}$ & Oil palm & 17,500 & & & \\
\hline 47 & 7 PT Bisma Dharma Kencana & $\begin{array}{l}\text { Cempaga, } \\
\text { Tewang and } \\
\text { Pulau Malan }\end{array}$ & Oil palm & $\begin{array}{l}15,000 \\
15,000\end{array}$ & 10,752 & 14,425 & 490 \\
\hline 48 & PT Mineralbumi Reksa Perdana & Mentaya Hulu & Oil palm & 15,000 & & & \\
\hline 49 & PT Indotruba Tengah & Hanau & Oil palm & 5,000 & & $\begin{array}{r}740 \\
2,905\end{array}$ & \\
\hline 50 & PT Indotruba Timur & $\begin{array}{l}\text { Seruyan tengah } \\
\text { dan hanau }\end{array}$ & Oil palm & 10,500 & & & \\
\hline 51 & PT Agro Buana Inti Lestari & Seruyan Tengah & Oil palm & $\begin{array}{l}15,000 \\
12,000\end{array}$ & & & \\
\hline 52 & PT Sampti Palma Sentosa & Baamang Tengah & Oil palm & 17,500 & & & \\
\hline 53 & 3 PT Lestari Unggul Jaya II & $\begin{array}{l}\text { Seruyan Tengah, } \\
\text { Hanau }\end{array}$ & Oil palm & 15,920 & & & \\
\hline
\end{tabular}


Appendix B. Continued

\begin{tabular}{|c|c|c|c|c|c|c|c|}
\hline & Company & Location & Commodity & $\begin{array}{l}\text { Location } \\
\text { Permit }\end{array}$ & $\begin{array}{l}\text { Release } \\
\text { of Forest } \\
\text { Land }(\mathrm{Ha})\end{array}$ & $\begin{array}{l}\text { Release of } \\
\text { Community } \\
\text { Land (Ha) }\end{array}$ & $\begin{array}{l}\mathrm{HGU} \\
(\mathrm{Ha})\end{array}$ \\
\hline 54 & $\begin{array}{l}\text { PT London Sumatra } \\
\text { Internasional }\end{array}$ & Cempaga & Oil palm & $\begin{array}{l}8,000 \\
8,000\end{array}$ & & & \\
\hline 55 & $\begin{array}{l}\text { PT Harapan Masawit } \\
\text { Bangun Persada }\end{array}$ & Danau Sembuluh & Oil palm & 14,000 & & & \\
\hline 56 & $\begin{array}{l}\text { PT Jorong Agro Lestari } \\
\text { Ex Pt Lautan Mustka Jaya }\end{array}$ & Kota Besi & Peternakan & 7,500 & & & \\
\hline 57 & PT Metaepsi Agro I & Seruyan Tengah & Oil palm & 5,000 & & & \\
\hline 58 & PT Metaepsi Agro II & Seruyan Tengah & Oil palm & 5,000 & & & \\
\hline 59 & PT Hati Prima Corporation & Mentaya Hutlu & Oil palm & 3,000 & & & \\
\hline 60 & PT Uniprima Com & Parenggean & Oil palm & 7,500 & & & \\
\hline 61 & PT Jaya Citra Persada & $\begin{array}{l}\text { Cempaga dan } \\
\text { Katingan Tengah }\end{array}$ & Oil palm & 15,000 & & & \\
\hline 62 & PT Jaya Citra Persada & Cempaga & Oil palm & 12,500 & & & \\
\hline 63 & PT Wanahasta Nusantara & $\begin{array}{l}\text { Katingan Tengah, } \\
\text { Mentaya Hulu }\end{array}$ & Oil palm & 15,000 & & & \\
\hline 64 & PT Astron Sumba Plantation & Mentaya Hulu & Oil palm & 25,000 & & & \\
\hline 65 & PT Karya Dewi Putra & $\begin{array}{l}\text { Katingan Hulu, } \\
\text { Marikit, mentaya H }\end{array}$ & $\begin{array}{l}\text { Oil palm } \\
\text { Hulu }\end{array}$ & 15,000 & & & \\
\hline 66 & PT Astana Karya & $\begin{array}{l}\text { Katingan Tengah, } \\
\text { Sananan Mantikei }\end{array}$ & Oil palm & $\begin{array}{l}12,000 \\
12,000\end{array}$ & & & \\
\hline 67 & PT Bina Sawit Pratama II & Seruyan Tengah & Oil palm & 10,000 & & & \\
\hline 68 & PT Mandahan River & Seruyan Hulu & Peternakan & 900 & & & \\
\hline 69 & PT Ciptani Kumai Sejahtera & Seruyan Tengah & Oil palm & 10,000 & & & \\
\hline 70 & PT Betang Tiara Pratama & & T udang & 5,000 & & & \\
\hline 71 & PT Agro Sawit Swadaya Mandiri & $\begin{array}{l}\text { Marikit } \\
\text { Katingan Hulu }\end{array}$ & Oil palm & 30,000 & & & \\
\hline 72 & PT Swadaya Sapta Putra & Seruyan Tengah & Oil palm & 7,500 & & & \\
\hline 73 & PT Agro Mandiri Perdana & Parenggean & Oil palm & 15,000 & & & \\
\hline 74 & $\begin{array}{l}\text { PT Harapan Mas Sawit } \\
\text { Bangun Perrsada Ex PT Lautan } \\
\text { Mustika Jaya }\end{array}$ & Danau Sembuluh & Oil palm & 14,000 & & & \\
\hline 75 & PT Agro Indomas & Danau Sembuluh & Oil palm & 3,860 & & & \\
\hline 76 & PT Agro Indomas & Danau Sembuluh & Oil palm & 1,000 & & & \\
\hline 77 & PT Bangkit Biat Usaha Mandiri & $\begin{array}{l}\text { Antang Kalang } \\
\text { Parenggean }\end{array}$ & Oil palm & 17,500 & & & \\
\hline 78 & $\begin{array}{l}\text { PT Bangun Jaya } \\
\text { Kelapa Permai }\end{array}$ & & Oil palm & 13,930 & & & \\
\hline & Total & & & ,384,483 & 220,481 & 22,960 & 116,293 \\
\hline
\end{tabular}


